\title{
Policies for a revitalisation of Japan
}

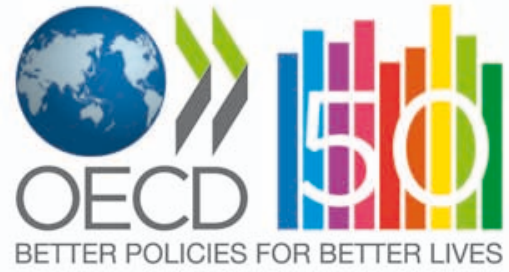



Better Policies

\section{Policies for a revitalisation of Japan}


This work is published on the responsibility of the Secretary-General of the OECD. The opinions expressed and arguments employed herein do not necessarily reflect the official views of the Organisation or of the governments of its member countries.

This document and any map included herein are without prejudice to the status of or sovereignty over any territory, to the delimitation of international frontiers and boundaries and to the name of any territory, city or area.

ISBN 978-92-64-20171-2 (PDF)

Series: Better Policies

ISSN 2308-1392 (online)

The statistical data for Israel are supplied by and under the responsibility of the relevant Israeli authorities. The use of such data by the OECD is without prejudice to the status of the Golan Heights, East Jerusalem and Israeli settlements in the West Bank under the terms of international law.

Photo credits: Cover @ Huebi - Fotolia.com

Corrigenda to OECD publications may be found on line at: www.oecd.org/publishing/corrigenda.

(c) OECD 2013

You can copy, download or print OECD content for your own use, and you can include excerpts from OECD publications, databases and multimedia products in your own documents, presentations, blogs, websites and teaching materials, provided that suitable acknowledgment of the source and copyright owner is given. All requests for public or commercial use and translation rights should be submitted to rights@oecd.org. Requests for permission to photocopy portions of this material for public or commercial use shall be addressed directly to the Copyright Clearance Center (CCC) at info@copyright.com or the Centre français d'exploitation du droit de copie (CFC) at contact@cfcopies.com. 


\section{Contents}

Foreword

Reviving growth

Achieving fiscal sustainability

Reforming the tax system

Strengthening the integration of Japan in the world economy

Strengthening Japanese education

Strengthening health and long-term care

Promoting social cohesion

Reducing gender inequality

Making growth greener

Reforming agricultural policy

Measuring well-being and progress 



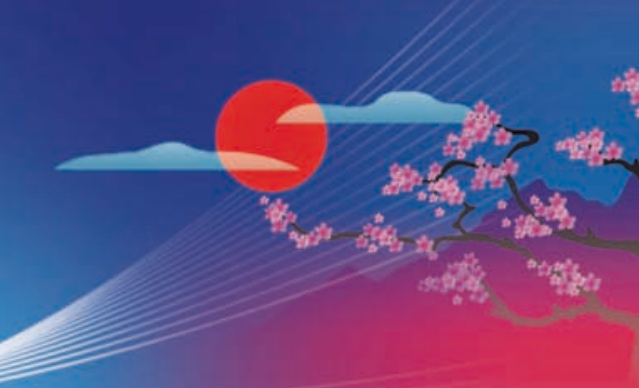

\section{Foreword}

The world has not yet fully overcome the worst economic crisis since the Great Depression. The global recovery remains fragile, public finances in many countries are in a dire state, inequality has risen. Restoring stability and confidence while strengthening growth and making it inclusive and sustainable over time remains a challenge for most OECD countries. Japan shares many of these challenges in the short run, because of the need for reconstruction and repair after the devastation from the Great East Japan Earthquake; in the longer run, because rapid population ageing will weigh on already strained public finances and further weaken potential growth.

Successfully addressing those challenges is essential not only for Japan but for the world at large. The Japanese authorities are fully aware of the extent of the task, as highlighted by the Strategies to Revitalise Japan.

Japan has several major strengths it can draw upon, in particular a very well-educated population, and will without doubt turn the Great East Japan Earthquake into an opportunity to strengthen its economy and society. But major reforms are needed on several fronts. A keystone of the Revitalisation strategy is tax reform, not only to boost revenues but also to support growth and make it greener and more inclusive. Reviving growth would therefore require greater integration of Japan in the world economy to foster competitiveness and innovation, reforming labour market institutions and policies, and creating more incentives for green innovation.

Identifying the main areas for reforms is not enough. They have to be carefully designed and effectively implemented. Drawing on OECD member countries' experiences, this brochure presents an update of key policy recommendations in areas that are critical to Japan's future: promoting growth, fiscal policy, tax reform, opening of the economy, education and skills, health and long-term care, reduction of income and gender inequalities, innovation and green growth, agriculture and overall well-being. The OECD looks forward to working with Japan to design and implement these policies and make the post-crisis world economy stronger, cleaner and fairer.

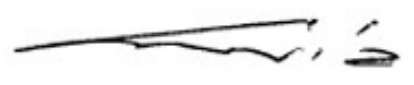

Angel Gurría

Secretary-General 


\section{Reviving growth}

Twenty years ago, Japan's per capita income matched the average of the top half of OECD countries (Figure 1). Since the collapse of the bubble economy, however, Japan has fallen behind. By 2010, its per capita income was $15 \%$ below the average of the top half of the OECD countries, putting it near the middle of the 34 member countries. While productivity has increased gradually relative to other OECD countries, it was too small to offset the decline in labour utilisation.

Stronger growth is essential to improve living standards and strengthen public finances, while bearing the costs associated with population ageing. Achieving stronger growth requires a two-pronged approach. First, it is essential to raise labour productivity growth, which has been increasing at a $1 \frac{1}{2}$ per cent annual rate during the past decade (per hour of labour input). Second, policies are needed to limit the decline in the labour force, which has fallen at nearly $1 \%$ a year, reflecting the decline in the working-age population. Together with fiscal sustainability, stronger growth is the main objective of the government’s Strategies to Revitalize Japan.

Figure 1. Despite a slight reduction recently Japan's gap in GDP per capita persists Gap with respect to the upper half of OECD countries ${ }^{1}$

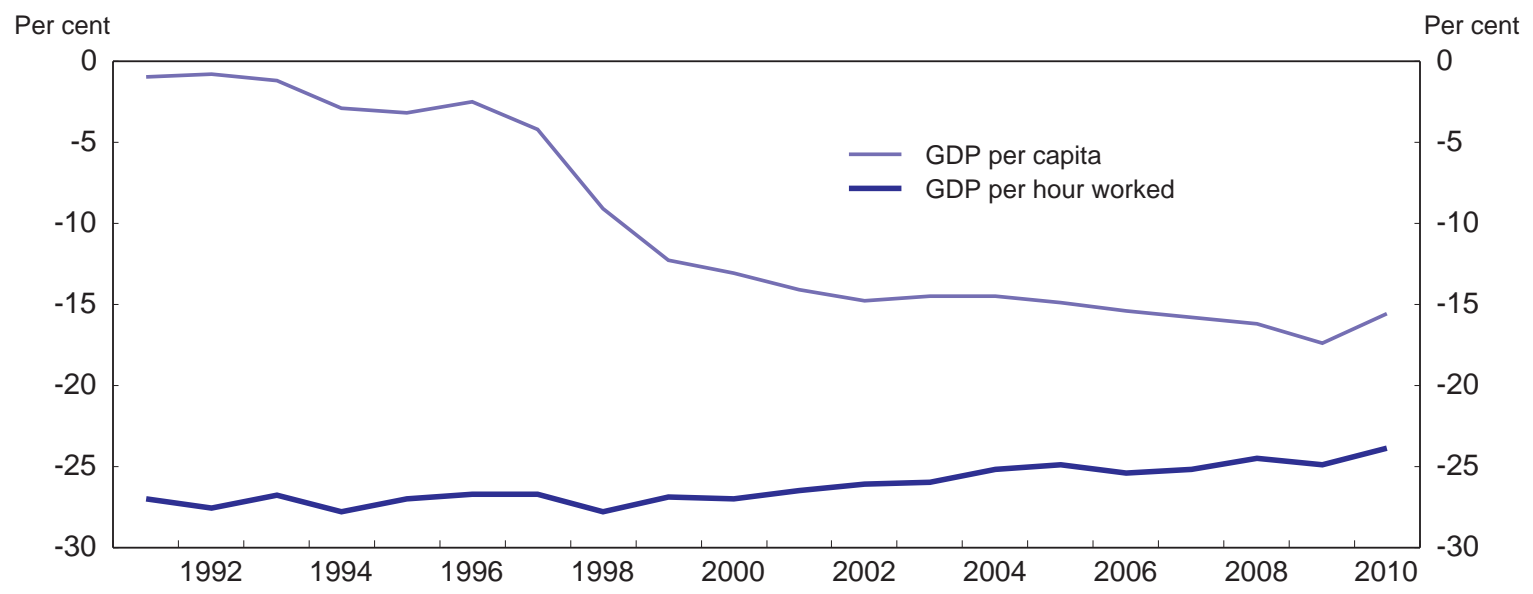

1 Percentage gap with respect to the simple average of the highest 17 OECD countries in terms of GDP per capita, GDP per hour worked and GDI per capita (in constant 2005).

Source: OECD, Going For Growth (2012).

\section{Increasing productivity}

Maintaining the good education performance should be a priority given its important link to economic growth. Countries with more human capital innovate faster, thereby achieving greater productivity gains. This requires improving the education system and adapting it to the new challenges of a fast-changing world. In addition, more training is needed for workers. However, the heavy reliance on non-regular employment tends to limit on-the-job training. Addressing the duality of the Japanese labour market is therefore a priority and would have the double benefit of reducing inequality while supporting growth. This requires a comprehensive approach, including an adjustment in the employment protection for regular workers combined with more training and better social insurance coverage of non-regular workers.

Japan is also a leading OECD country in terms of R\&D, although this is not fully reflected in its innovation performance. Co-operation among universities, government and research institutes needs to be enhanced through greater mobility of researchers and boosting the share of public research funds for universities that is allocated competitively. Upgrading tertiary education, in part through stronger competition and internationalisation, would not only increase human capital but would also boost the role of universities in innovation.

Stronger competition and regulatory reforms in the service sector would not only boost innovation but also support the productivity of services which has lagged behind that in manufacturing in recent years. This is all the more important, given that services account for $70 \%$ of valueadded and employment in Japan. Strengthening competition is the key to improving productivity in this sector. First, competition policy should 


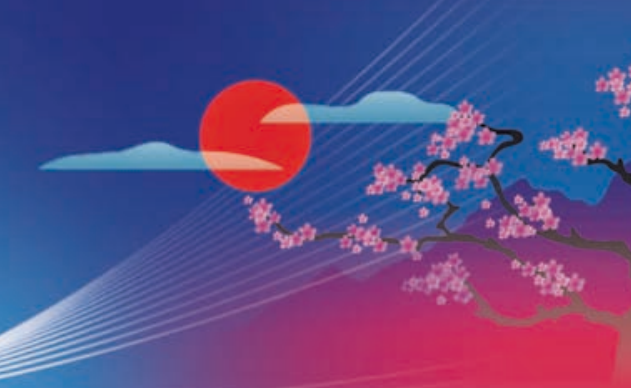

be further upgraded by reducing exemptions to the Anti-Monopoly Act, increasing administrative fines and ensuring a level playing field by phasing out the special treatment of SMEs, which play a dominant role in services. Second, regulatory reform should be accelerated, focusing on reducing entry barriers, as international comparisons indicate that starting a business in Japan is relatively complicated, costly and time-consuming. Third, international competition should be enhanced by reducing barriers to service imports and encouraging inward foreign direct investment. In addition, competition in key service industries, such as retail, energy, transport and business services, needs to be strengthened through wide-ranging reforms.

Figure 2: Comparative strengths and weaknesses in competencies and capacities to innovate, 2011 Normalised index of performance relative to the median values in the OECD area (Index median=100)

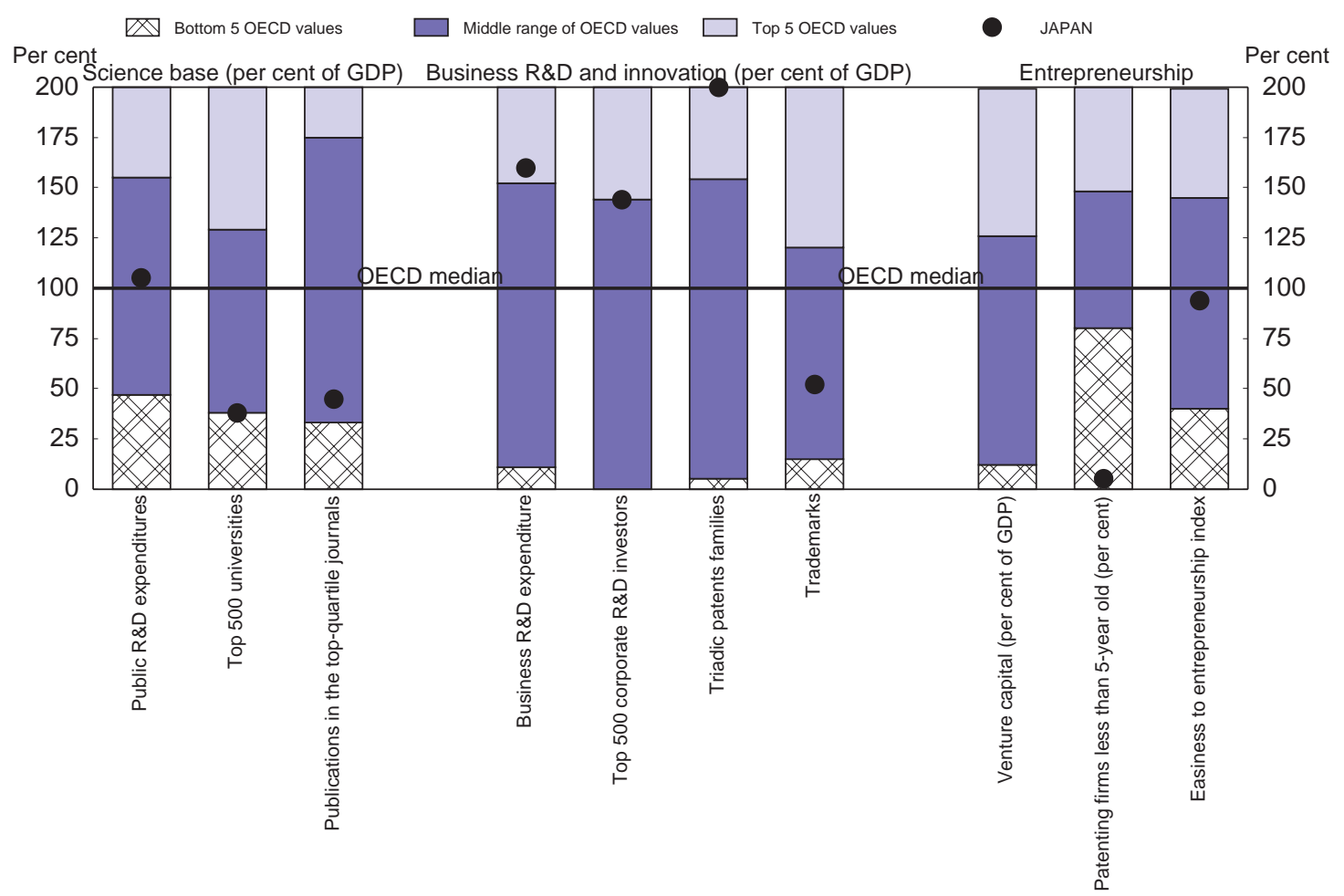

Source: OECD (forthcoming), OECD Science, Technology and Industry Outlook 2012, OECD, Paris.

\section{Limiting the decline in labour supply}

The impact of the decline in the working-age population could be moderated by increasing female participation in the labour market. This requires fundamental changes in employment practices, childcare policies and the tax system. Another priority is to take advantage of older workers through more flexible employment and wage systems to raise the age at which they leave firms. Immigration, notably of highly skilled workers, also has a role to play to limit the impact of the shrinking Japanese labour force on long-term growth.

\section{Key OECD recommendations}

- Reduce labour market dualism.

- Further open the economy to foreign goods, capital and workers.

- Improve the framework for innovation.

- Boost productivity in the service sector through reforms that strengthen competition.

- Mitigate the decline in the labour force by boosting participation, particularly of women. 


\section{Achieving fiscal sustainability}

\section{Japan's fiscal situation has reached a critical point}

Since the collapse of the asset price bubble in the early 1990s, numerous fiscal stimulus packages and rising social outlays, due in part to population ageing, have driven up government spending. Meanwhile, a prolonged period of weak economic growth and tax cuts have constrained revenue, resulting in two consecutive decades of budget deficits.

The steady string of deficits through periods of expansion and recession alike indicates that the problem is more structural than cyclical in nature (Figure 1). Indeed, borrowing exceeded tax revenue for the fourth straight year in the FY 2012 draft budget (central government general account, initial budget basis). In addition, planned reconstruction spending of around 19 trillion yen (about 4\% of GDP) over the five years following the 2011 Great East Japan Earthquake is further exacerbating the fiscal situation in the short run, although planned increases in taxes over the next 25 years will eventually cover the cost of reconstruction.

Figure 1. Widening gap between expenditure and tax revenue

General account of the central government in trillion yen ${ }^{1}$

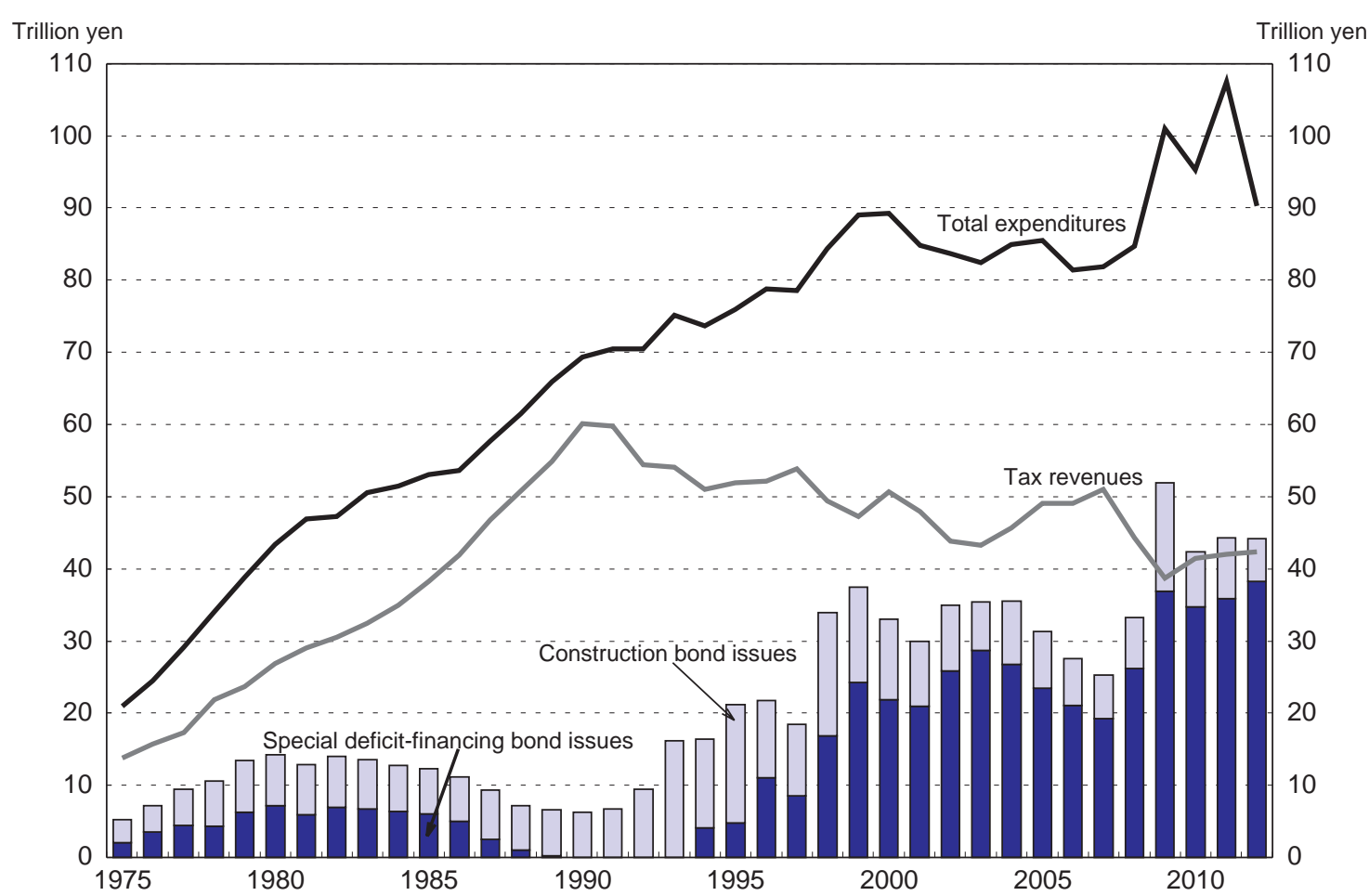

1. The final budget for FY 1975 to 2010; the revised budget for FY 2011; and the initial budget for FY 2012. Source: Ministry of Finance.

\section{Japan's public debt ratio is a major source of vulnerability}

Gross public debt has risen rapidly to uncharted territory at around 200\% of GDP, the highest ever recorded in the OECD area (Figure 2), and is expected to increase further given a budget deficit of around $9 \%$ of GDP (excluding one-off factors) in 2011-12. Although the impact of the extraordinary level of debt has been mitigated thus far by very low long-term interest rates, Japan is vulnerable to a loss of market confidence in the sustainability of its public finances and a run-up in long-term interest rates.

Higher long-term rates would seriously damage the budget and the real economy. According to a government estimate, a one percentage-point increase in bond yields would add 1 trillion yen ( $0.2 \%$ of GDP) to debt servicing costs in the first year, rising to 4.1 trillion yen ( $0.9 \%$ of GDP) in the third year. The challenge for Japan is to improve its fiscal situation before the period of low interest rates comes to an end and rising interest payments on the accumulated debt result in a further deterioration in the fiscal situation. 


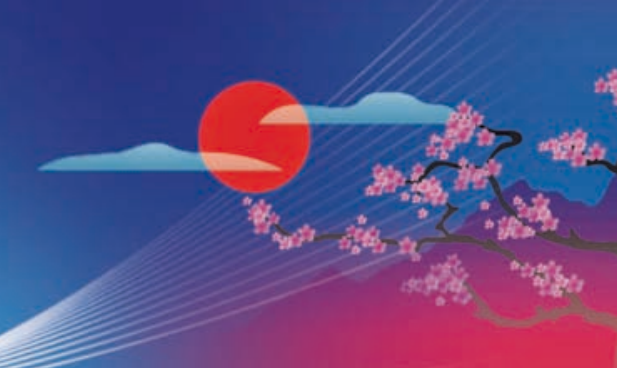

Figure 2. Public debt in selected OECD countries ${ }^{1}$
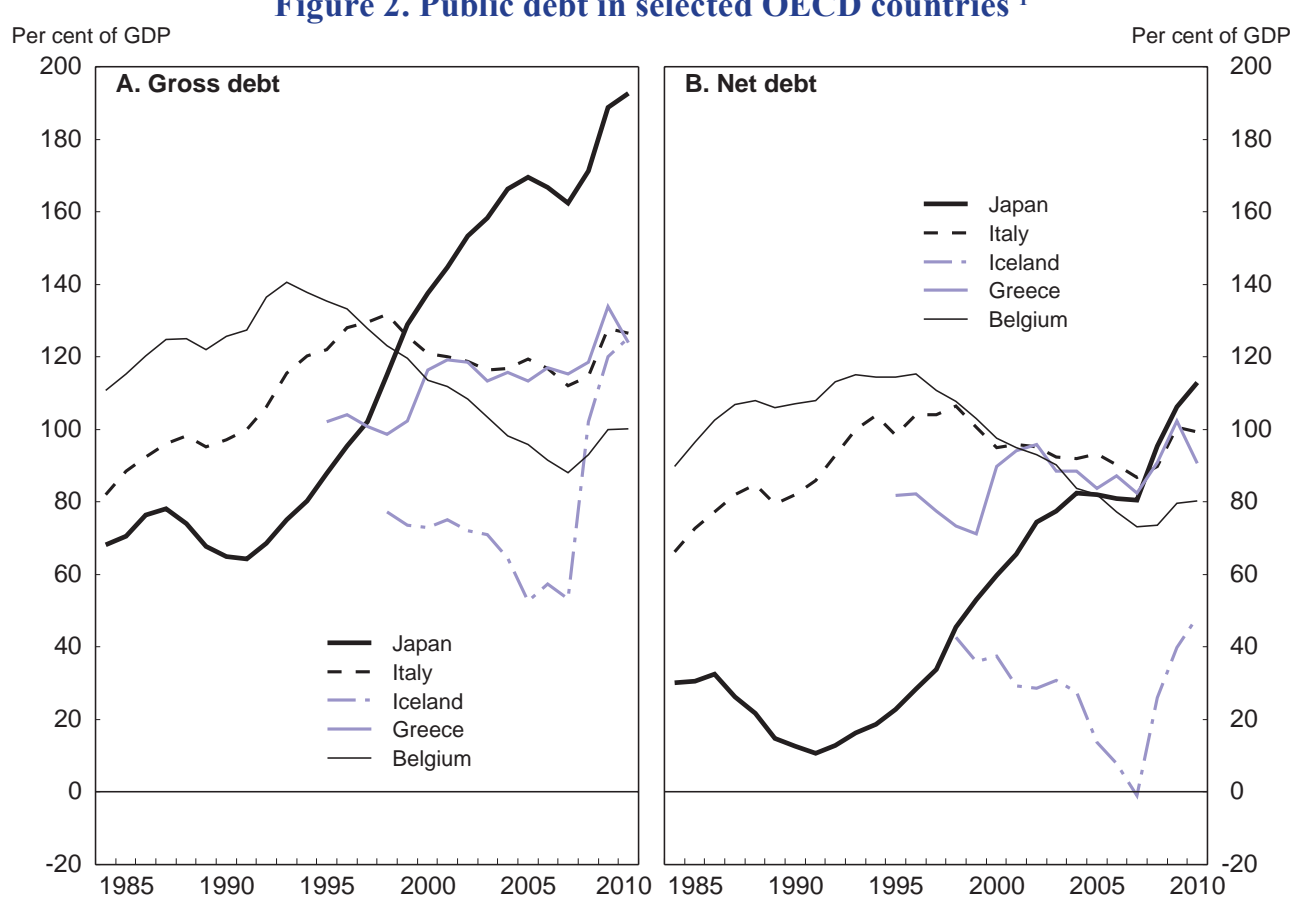

1. The five countries in the OECD area with gross debt of more than $100 \%$ of GDP in 2010. Debt is based on the National Accounts definition measured in market prices.

Source: OECD Economic Outlook Database.

\section{A detailed and credible fiscal consolidation plan}

Achieving the government's goal of a primary budget surplus (for central and local governments) by FY 2020 and putting the public debt ratio on a downward trend from FY 2021 will require both spending cuts and revenue increases to achieve a large enough primary budget surplus. Compared to other OECD countries, Japan has a relatively small government, with total spending the sixth lowest in the OECD area as a share of GDP, suggesting that the consolidation will have to be largely revenue based.

A detailed and credible fiscal consolidation plan including both revenue increases and spending cuts is essential to maintain confidence in Japan's fiscal situation. OECD experience also suggests that a stronger fiscal policy framework would foster the credibility of the medium-term fiscal plan. This requires a mutually reinforcing framework of budget procedures, fiscal rules and oversight by an objective fiscal body at arm's-length from the policy-making process to monitor and evaluate progress in implementing the plan. In addition, fiscal oversight at the local government level needs to be upgraded.

\section{Key OECD recommendations}

- Maintain confidence in the fiscal situation by creating a detailed and credible fiscal consolidation plan that includes both spending cuts and revenue increases.

- Implement the government's proposal to double the consumption tax rate in two stages to 10\% by 2015.

- Implement well-targeted social policies, including for low-income earners, to promote social cohesion.

- Reform social security programmes to limit spending increases, while providing a sound funding source for pensions.

- Cut spending in areas such as government wage costs and public investment in the medium term.

- Improve the fiscal policy framework to bolster confidence in a medium-term fiscal plan. 


\section{Reforming the tax system}

\section{Raising tax revenues while promoting growth}

Reforming the tax system provides an opportunity to support growth in the long term while raising the additional revenues needed to restore fiscal sustainability. Tax revenues, which are the fifth lowest in the OECD (Table), have a major role to play in addressing the fiscal situation. The short-term negative impact of higher taxation on growth can be mitigated by several measures, including shifting its composition toward indirect taxation and broadening the tax base. Such a comprehensive tax reform will support Japan's growth potential through several channels, including the competitiveness of the corporate sector, and promote green growth while addressing inequality.

Tax revenues in 2010 in major OECD economies (per cent of GDP)

\begin{tabular}{|l|c|c|c|c|c|c|c|c|}
\hline & Canada & France & Germany & Italy & Japan $^{1}$ & UK & US & $\begin{array}{c}\text { OECD } \\
\text { average }^{2}\end{array}$ \\
\hline $\begin{array}{l}\text { Total tax and } \\
\text { contributions }\end{array}$ & $\mathbf{3 1 . 0}$ & $\mathbf{4 2 . 9}$ & $\mathbf{3 6 . 3}$ & $\mathbf{4 3 . 0}$ & $\mathbf{2 6 . 9}$ & $\mathbf{3 5 . 0}$ & $\mathbf{2 4 . 8}$ & $\mathbf{3 3 . 9}$ \\
\hline Personal Income tax & 10.8 & 7.3 & 8.9 & 11.7 & 5.4 & 10.0 & 8.0 & 8.4 \\
\hline Corporate income tax & 3.3 & 2.1 & 1.5 & 2.8 & 2.8 & 3.1 & 2.7 & 2.9 \\
\hline $\begin{array}{l}\text { Social security } \\
\text { contributions }\end{array}$ & 5.4 & 18.0 & 14.2 & 13.6 & 11.0 & 6.7 & 6.5 & 9.5 \\
\hline Consumption tax & 7.5 & 10.7 & 10.7 & 11.1 & 5.1 & 10.8 & 4.5 & 11.0 \\
\hline
\end{tabular}

1. Japan - data are for 2009.

2. Unweighted average; 2010 estimate derived from 2009 data plus average change in 2010 compared with 2009 for those countries reporting 2010 data.

Source: OECD, Revenue Statistics 2011.

\section{Broadening the direct tax base while reducing rates}

Personal income tax revenues are especially low in Japan and revenues from social security contributions are much lower than in continental European countries. As a result, the tax wedge on labour income for workers earning the average wage was estimated at $30.5 \%$ in 2010 , well below the OECD average of $34.9 \%$. Maintaining a low tax wedge is important for long-term growth and employment. Additional personal income tax revenue should therefore come from a broader base, including the removal of exemptions from income tax for spouses with low earnings which create disincentives for female employment.

Corporate income tax revenues are close to the OECD average, as the impact of a relatively high tax rate (39.5\% in 2011 compared to the OECD average of 25.5\%) is offset by a comparatively narrow tax base. The high tax rate on corporate income weakens Japanese firms' competitiveness, while the numerous exemptions distort the allocation of resources and investment. Cutting the corporate tax rate and widening its base would hence stimulate economic activity without necessarily reducing revenues. In 2012, the central government tax rate was cut from $30 \%$ to $25.5 \%$, although this is largely offset by the temporary $10 \%$ surtax on corporate income to help finance reconstruction following the earthquake.

\section{Shifting the composition of taxes from direct to indirect taxes}

Japan's general consumption tax, which is a value-added tax (VAT), yields only 2.6\% of GDP of revenues, less than half of the OECD average of $6.7 \%$. This reflects a standard rate of only 5\%, the lowest among OECD countries and well below the OECD's unweighted average of $18.5 \%$. There is thus sizeable scope to raise additional revenues in a relatively neutral, non-distorting way from this consumption tax.

The Japanese government has proposed doubling the VAT rate, in two steps to $10 \%$ by October 2015. It is important to maintain the single rate structure, which has the advantage of avoiding distortions in consumer choices. The negative impact on income distribution should be addressed through other measures targeted on low income earners, such as an earned income tax credit. 

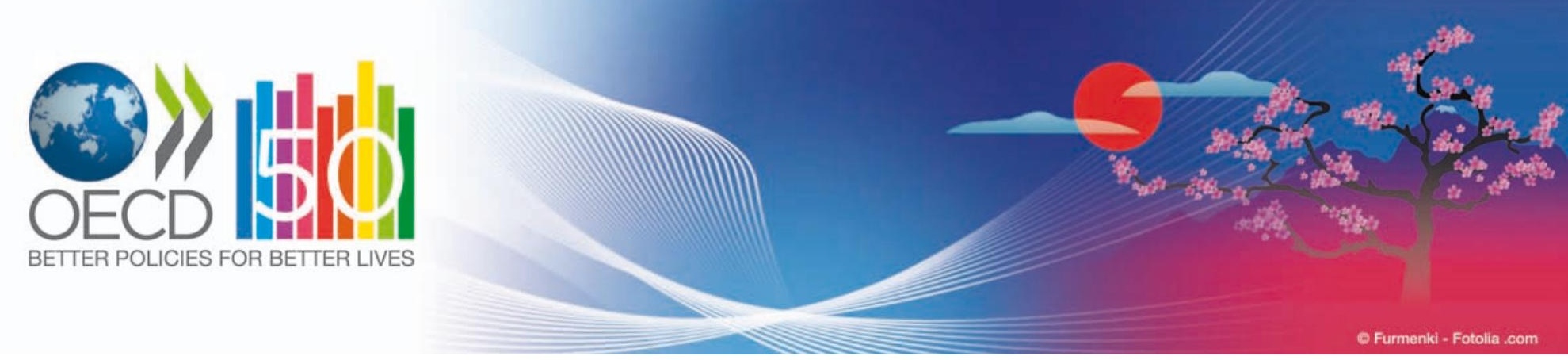

Environmentally oriented indirect taxes are still low relative to other OECD countries. Further broadening the use of such taxes would have the double benefit of raising additional revenue while providing better environmental incentives.

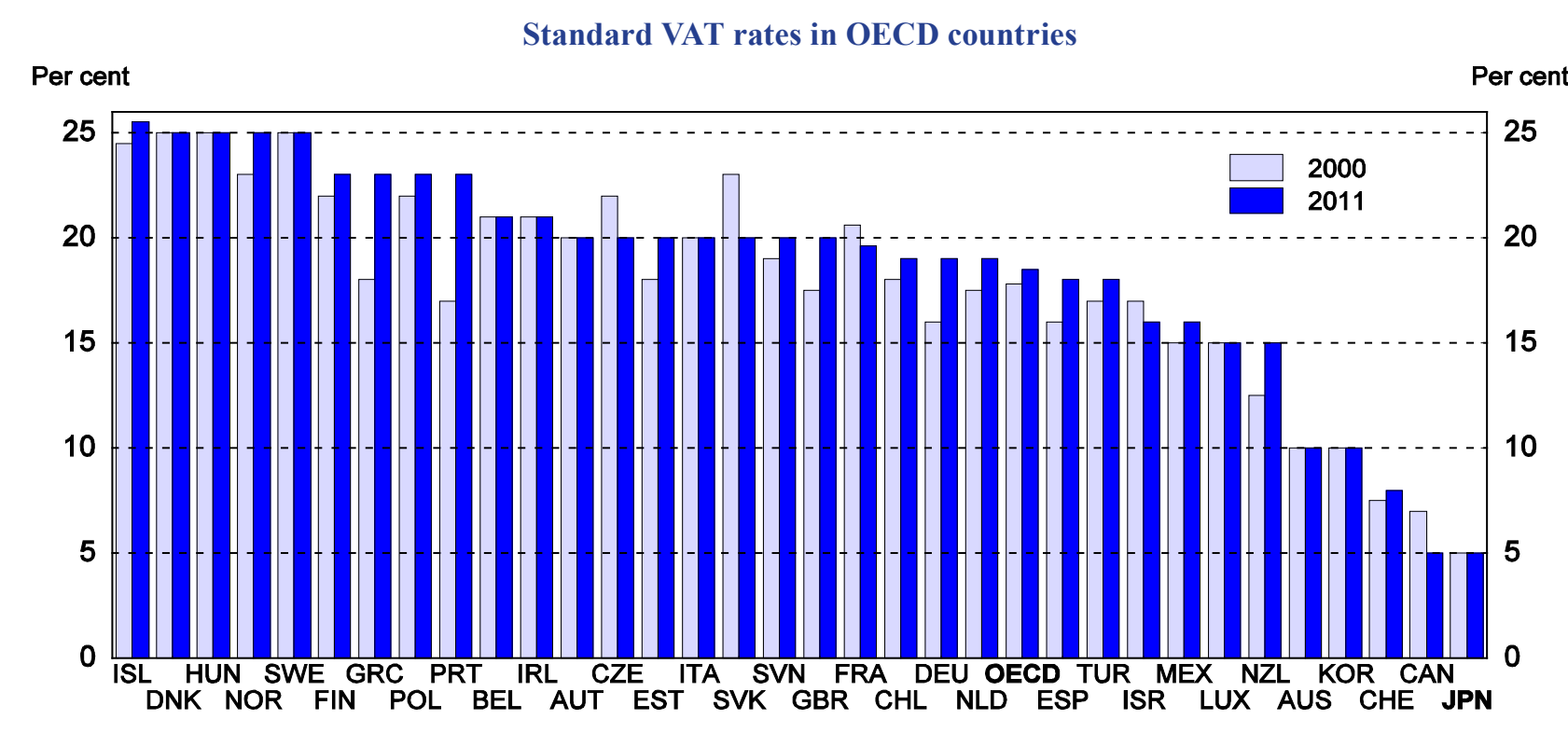

Source: OECD, Revenue Statistics 2011.

\section{Improving the local tax system}

The local tax system is exceptionally complicated with many taxes and only limited autonomy for local governments. A comprehensive tax reform should reduce barriers to the effective use of existing powers to set local tax rates, and encourage local governments to rely primarily on existing local taxes on personal income, consumption and property, as they are relatively stable.

\section{Key OECD recommendations}

- Broaden the base of the corporate and personal income tax to increase revenues.

- Reduce the corporate income tax rate to increase competitiveness.

- Increase the consumption tax rate while maintaining the single rate structure.

- Introduce new environmentally-oriented indirect taxes.

- Improve the local tax system, while granting more autonomy to local governments. 


\section{Strengthening the integration of Japan in the world economy}

\section{The Japanese economy remains relatively closed}

While Japan's tariff rates are among the lowest in the world, other trade barriers remain significant, as measured by the World Bank's Overall Trade Restrictiveness Index, which includes non-tariff measures. Such restrictions limit Japan's import penetration ratio, which at 12.4\% in 2009 was well below the OECD average of $46.3 \%$. In addition, the level of Japan's intra-industry trade is relatively low compared to other large economies. Moreover, while Japan has been an active investor overseas, the stock of FDI in Japan was also the lowest among OECD countries at 3.9\% of GDP in 2010, due in part to barriers to foreign investment. In addition, Japan also appears to have the lowest stock of foreign workers in its labour force among the countries for which data are available. Foreign residents with work permits for high-skilled occupations accounted for only $0.3 \%$ of the total labour force in 2008, the lowest share among OECD countries.

Share of foreign-controlled affiliates in turnover in manufacturing and services (2009)

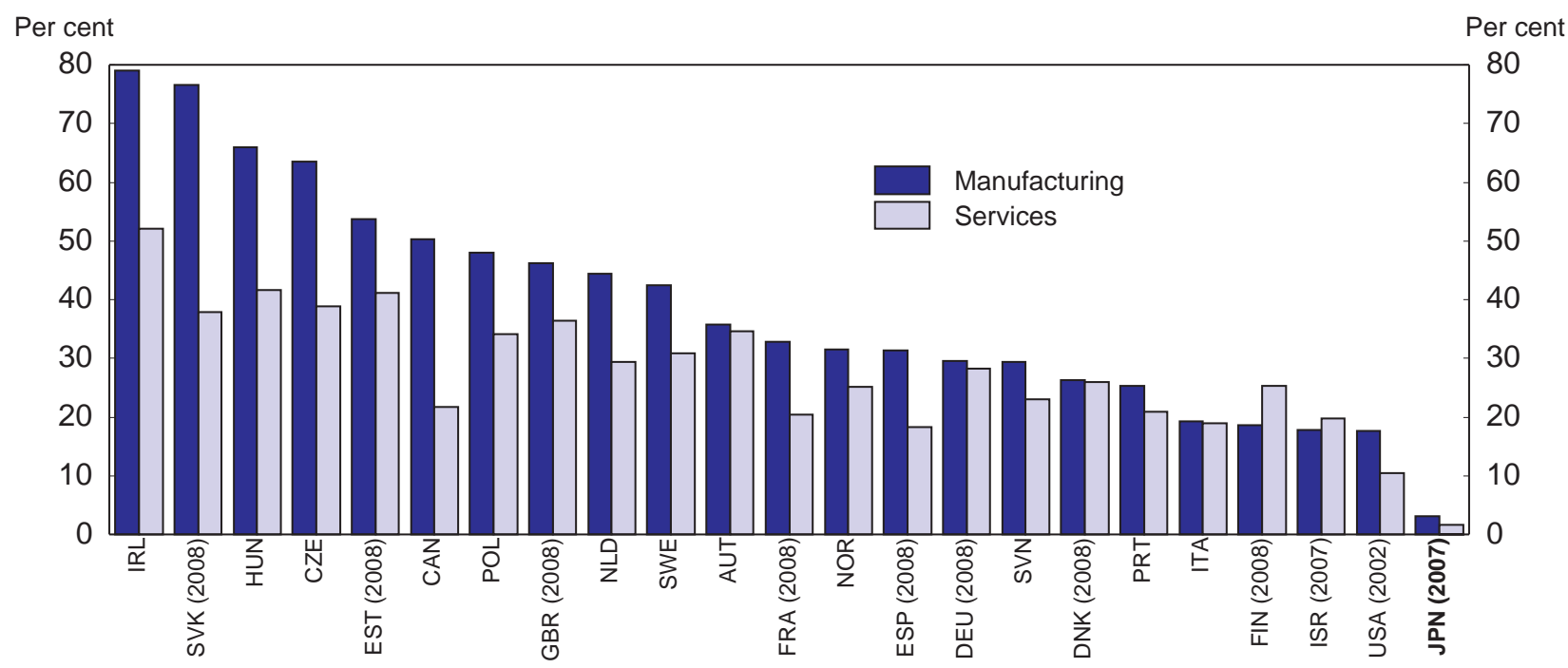

Note: Turnover in services does not include financial intermediation in all countries except Canada and community, social and personal services in all countries except Canada, Estonia, Israel and Japan.

Source: OECD, AMNE database, April 2012.

\section{Increased openness would help revitalise the economy}

The government has recognised the need to increase Japan's openness. Access to imported inputs and inflows of FDI not only reduce costs but also enhance productivity through technology spillovers and improved competitiveness. This would help boost Japan's growth potential in the face of a number of headwind shocks. Fewer non-tariff measures would better enable Japanese firms to access the efficiency gains and opportunities for innovation by further developing global supply chains. Immigration also has a role to play to limit the impact of the shrinking Japanese labour force on long-term growth and the sustainability of public finances. Moreover, further internationalisation of graduate education will help Japan to boost performance and develop globally-competitive talent.

A core objective of the New Growth Strategy is to increase integration with the world economy. This Strategy has set a goal of doubling the inflow of people, goods and capital by 2020, in part by reducing barriers to trade and restrictions on foreign investment and the movement of people into Japan. 


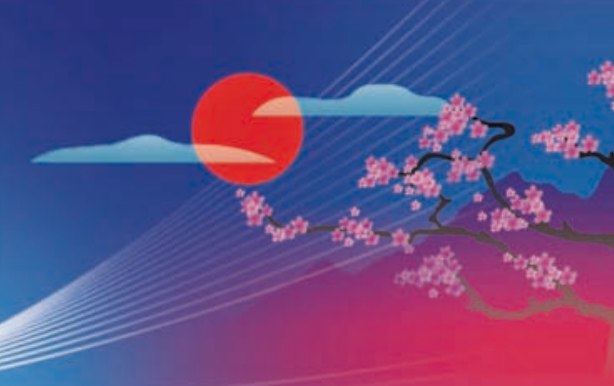

Japan is also pursuing greater openness through regional trade agreements with major trading partners. Japan has implemented 13 Economic Partnership Agreements (EPAs) in the past decade, covering about one-fifth of Japanese exports and imports, and has signaled its intention to continue this initiative. Importantly, in 2011 Japan entered into consultations with those countries participating in the Trans-Pacific Partnership (TPP) negotiations. This is a welcome development and a further indication of Japan's commitment to open markets.

\section{Key OECD Recommendations}

- Pursue comprehensive EPAs with major trading partners and participate in the TPP negotiations, including by scaling back protection in sectors where it is highest.

- Reduce non-tariff trade barriers with a view to increasing productivity and innovation.

- Improve the climate for FDI inflows by further liberalising trade, lowering barriers to investment and ownership, accelerating regulatory reforms particularly in services, simplifying administrative procedures and market access, and relaxing labour regulations.

- Liberalise controls on immigration to allow more foreign students and high-skilled workers in Japan. 


\section{Strengthening Japanese education}

The education system is one of the main strengths of Japan. In particular, Japan has achieved outstanding scores on the OECD PISA assessments. But it needs to further improve educational outcomes in the face of tight resource constraints, rapid population ageing and economic change.

Comparison of student performance in the PISA assesment on reading in 2009

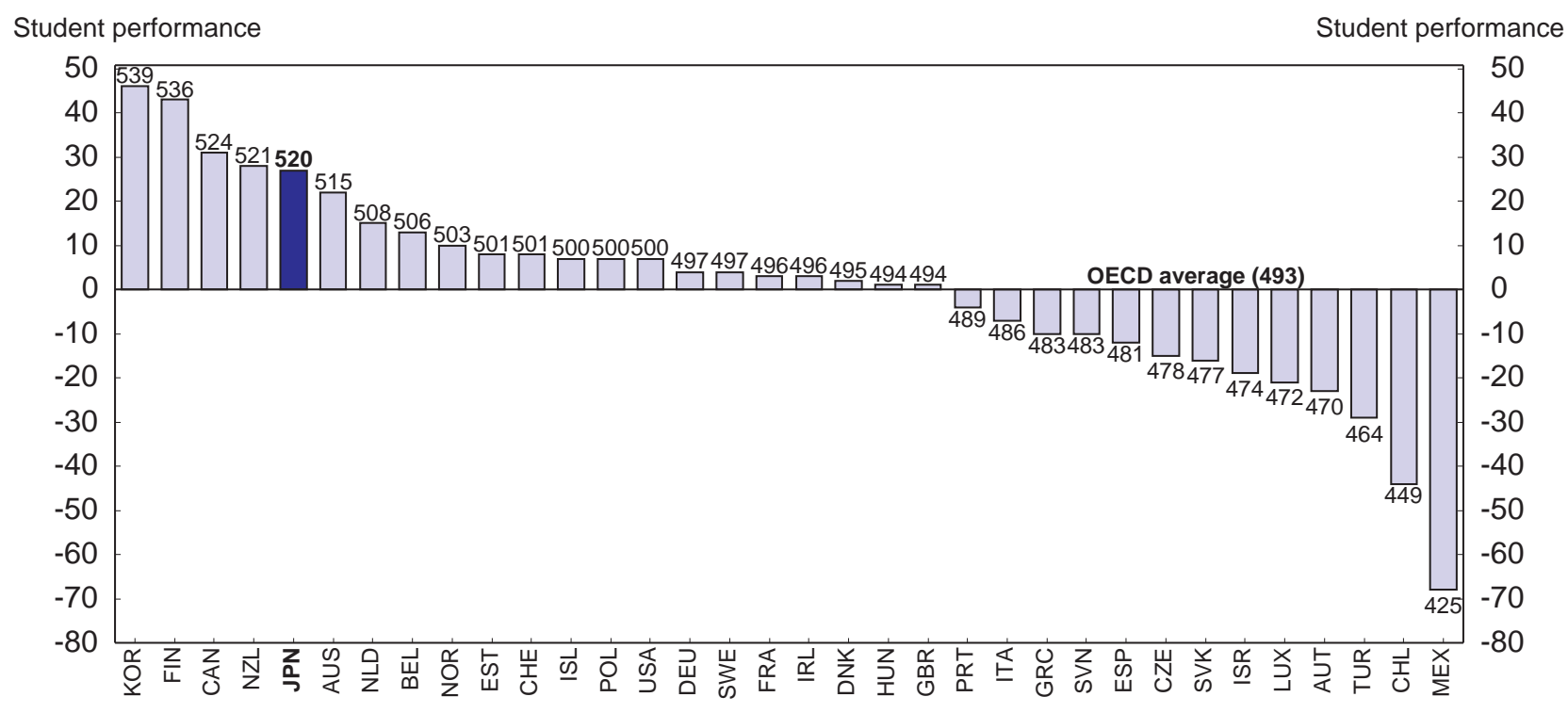

Source: OECD (2010), PISA 2009 Results: What Students Know and Can Do, Volume 1.

\section{Adapting to a changing world}

Results from the successive PISA assessments show that despite significant progress over the past decade many Japanese students still struggle with tasks requiring them to creatively use and apply knowledge in novel situations. Continued reform of standards and curricula, and their effective implementation in classrooms, will therefore be essential. Equally important is a shift from qualifications-focused education upfront to demand-sensitive learning throughout life. Today, education needs to prepare individuals to adapt to fast social and economic change, for jobs that have not yet been created and to use technologies that do not yet exist. Economic value is increasingly created through the capacity of individuals to innovate and collaborate, rather than vertically through command and control.

\section{Reviewing teacher and school policies}

Over the past decade, Japan has prioritised reductions in class sizes over investments in the quality of teachers. In the future, the quality of teaching will require similar attention. Japanese teachers are asked to keep up with innovations in curricula, pedagogy and digital resources, to deal with increasing diversity in their classrooms, and to cope with long working hours. Japan thus needs to rethink some of its approaches to teacher policies, including how to make the teaching profession more respected and attractive for its most talented graduates; the initial education of teachers, how they are monitored, and the continuing education and support they receive; how their compensation is structured; and how the performance of struggling teachers is improved. Local capacity and initiative will play a central role in directing efforts to "creative futures".

Japan has already seen a significant shift from one of the more centralised to one of the more decentralised school systems. However, the challenge remains to enable teachers, schools and local communities to actively assume the leadership responsibilities they have been assigned. This, in turn, will demand greater attention to equity-related issues. PISA shows that Japan's traditionally high standards of equity are beginning to erode and disadvantaged students tend to perform worse than expected when they attend disadvantaged schools. Such differences are larger than in many other OECD countries. Devolution, therefore, needs to be accompanied 


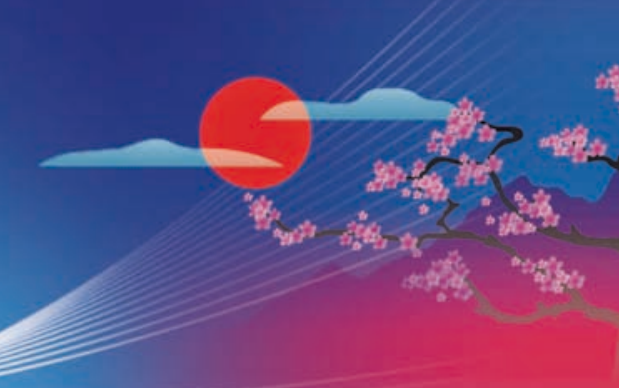

by policies that attract the most talented teachers to the most challenging classrooms and the most capable principals to the schools most in need for effective leadership.

The prominence of juku, which provides additional instruction to about half of middle-school and a quarter of primary-school students, raises also some equity concerns as attendance at juku rises with family income. Reducing dependence on juku can help to improve equity in the distribution of learning opportunities and decrease the financial burden on households.

\section{Strengthening lifelong learning}

Learning does not begin in school nor does it end with school. Japan's effort to integrate childcare centres and kindergartens and to build a coherent educational framework for children will be central to providing all children, regardless of their socio-economic background, with the best possible start in life. Similarly, in the current demographic context, Japan will need to do better in leveraging the competencies and capacity to learn of its adult population. Upgrading tertiary education through greater competition and internationalisation would enhance the skills of young people. In addition, Japan needs to shift the focus from qualificationsfocused education upfront to demand-sensitive learning throughout life, and translate improved skills into better economic and social outcomes.

\section{Financing education}

It is important to improve value for money in the education system, particularly in the context of Japan's constrained public finances. Looking ahead, reducing public debt and coping with changing demographics, with the associated demand for social services, will put even more pressure on investment in education. Further increasing value for money must be a priority, in part through integrating childcare and kindergarten, which is also essential for improving the quality of early childhood education and care, and by establishing an efficient framework for school consolidation in the face of falling enrolments.

\section{Key OECD recommendations}

- Reinvigorate curricula to foster more creative skills.

- Raise the quality of teaching by making the teaching profession more respected and more attractive for Japan's most talented graduates, including reviewing the training and pay of teachers and how the performance of struggling teachers is improved.

- Fully benefit from the devolution of decision-making in education by enabling teachers, schools and local communities to actively assume their new roles and attract the most talented teachers to the most challenging classrooms in order to improve equity.

- Ease the financial burden of education on households.

- Build a coherent framework for early childhood education and care to provide all children with the best possible start in life, in part by integrating childcare and kindergarten to enhance educational opportunities for children in childcare.

- Raise the competencies and capacity of its adult population and shift focus from qualifications-focused education upfront to demand-sensitive learning throughout life.

- Further increase value for money spent on education. 


\section{Strengthening health and long-term care}

In 2011, Japan celebrated the 50th anniversary of achieving universal health coverage. The country's healthcare system has contributed to the outstanding health status of the population while keeping public spending on health at around the OECD average. However, the health-care system now faces serious challenges: technological change and population ageing are putting upward pressures on health and long-term care spending, while a shrinking working-age population is making it more difficult to provide and pay for health and long-term care.

\section{Increasing the efficiency of the health-care system}

OECD Health Data suggests that there is room to improve efficiency, allowing Japan to maintain, or even increase, the quality of the health-care system while lowering its costs. Indeed, Japan has the highest number of diagnostic machines per capita among OECD countries (Figure), and the use of health services (physician consultations and hospital stays) is also the highest due, in part, to the reliance on fee-for-service payments. In this context, efficiency gains could be achieved by improving the fee-setting process, reforming the Diagnostic Procedure Combination (DPC) and introducing performance-based payments, as in other OECD countries.

International comparison of health-care services

OECD average=100, in 2009 or latest year

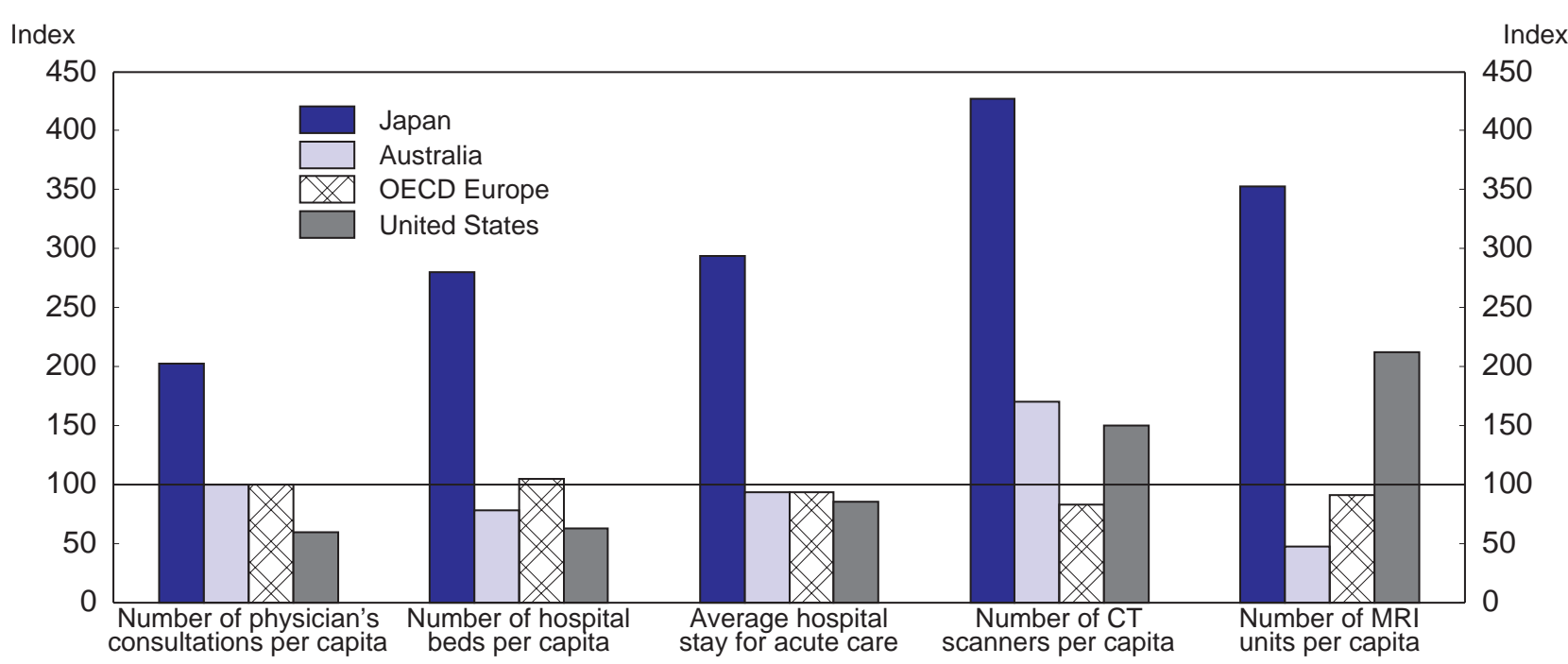

Source: OECD Health Data 2011.

Other areas where efficiency gains could be achieved include greater use of generic drugs to reduce pharmaceutical drug expenditures, consolidation of health insurers, restructuring of hospitals; and further promotion of community-based options for health and long-term care delivery.

\section{Enhancing access to and the quality of health-care}

The quality of health care is good in many areas, including cancer care and acute treatment for stroke. However, there is still room for improvement in some areas. First, Japan has one of the lowest ratios of physicians to population in the OECD, putting severe pressure on physicians, especially in the hospital sector, where many physicians work extremely long hours. Steps have been taken to increase the number of students in medical schools, but given the time lag in training physicians, additional measures, such as encouraging greater tasksharing among doctors, nurses and other health workers in delivering certain health services, need to be considered. 


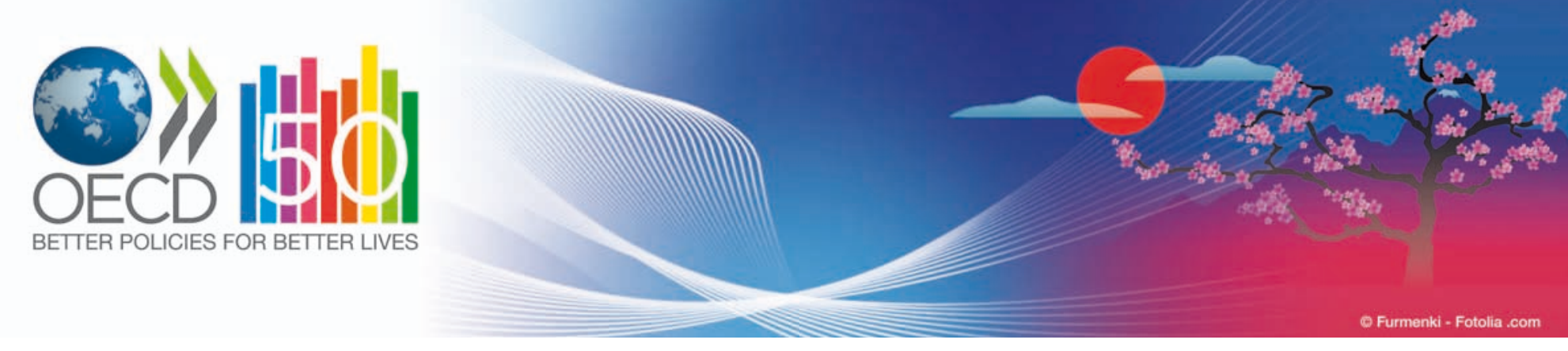

Additional reforms would improve the quality of health care-supply. In particular, a more rigorous certification process for specialists is needed. In addition, only about a quarter of all hospitals are currently accredited, pointing to the need for a more systematic assessment to ensure that all hospitals are properly inspected and evaluated. Greater efforts at measuring, evaluating and comparing quality of care would promote accountability among health-care providers, thereby empowering patient,, and encouraging evidence-based health policy-making. More effective intervention and better coordination between care providers are also needed in some areas, notably regarding patients who have suffered a heart attack.

\section{Improving the delivery of long-term care and promoting healthy ageing}

Japan's public spending on long-term care (LTC) is expected to more than triple in coming decades, rising from $1.4 \%$ of GDP in 2007 to as high as $4.4 \%$ in 2050. Reducing potential dependency in later life through lifelong health promotion can help to mitigate the growth in LTC expenditure. In 2006, the Japanese government introduced a community-based, prevention-oriented LTC benefit in the long-term care insurance system. The aim is to prevent seniors in need of low levels of care from becoming dependent by providing services targeted at improving their physical condition, mental health and nutritional status.

Japan could further implement policies to reduce the excessive use of hospital beds for long-term care purposes, which partly accounts for the Country's high number of hospital beds per capita. Promoting the provision of home and community-based care responds both to the wishes of most elderly people to receive long-term care at home and to the need to control cost.

\section{Key OECD recommendations}

- Improve efficiency by basing the payment systems on a more rigorous evaluation of clinical and costeffectiveness.

- Expand the use of generic drugs by making them the standard for reimbursement.

- Alleviate physicians' excessive workload in the hospital sector by training more doctors and promoting task-sharing.

- Improve quality by implementing a more systematic process for certifying medical specialists and accrediting hospitals and monitoring and evaluating quality of health and long-term care on a regular basis.

- Support the further provision of home and community-based long-term care to respond to patients' preferences and control cost while reducing the use of hospital beds for long-term care.

- Promote healthy ageing in order to reduce dependency. 


\section{Promoting social cohesion}

\section{Reducing the duality of the labour market to reverse rising income inequality}

Inequality among working-age people in Japan is somewhat above the OECD average in terms of the Gini coefficient (Figure 1). Moreover, the top 10\% of Japanese earn ten times more than the bottom 10\%, compared to an average of nine in the OECD area. As in most other OECD countries, inequality has risen since the mid1980s. This increase has been driven by the rising share of non-regular workers in total employment, which has doubled since 1990 to almost 34\% in 2010. Firms hire non-regular workers in order to achieve employment flexibility, given the higher employment protection given to regular workers, and to reduce labour costs. Nonregular workers are paid substantially lower wages, tend to work fewer hours and change jobs frequently. Only $28 \%$ of firms provide on-the-job training for non-regular workers, less than one-half the proportion for regular workers. Only two-thirds pay employment insurance contributions for their non-regular workers, who bear the brunt of cyclical changes in employment, and less than half pay work-related health and social insurance contributions.

Non-regular work is frequent among youth and older workers, who are reemployed at lower wages after they reach the occupational retirement age (typically 60) and until they reach the public pension age (65). The limited opportunities for non-regular employees to move into regular jobs deepen labour market segmentation and increase inequality.

Figure 1. Levels of income inequality in OECD countries, late 2000s

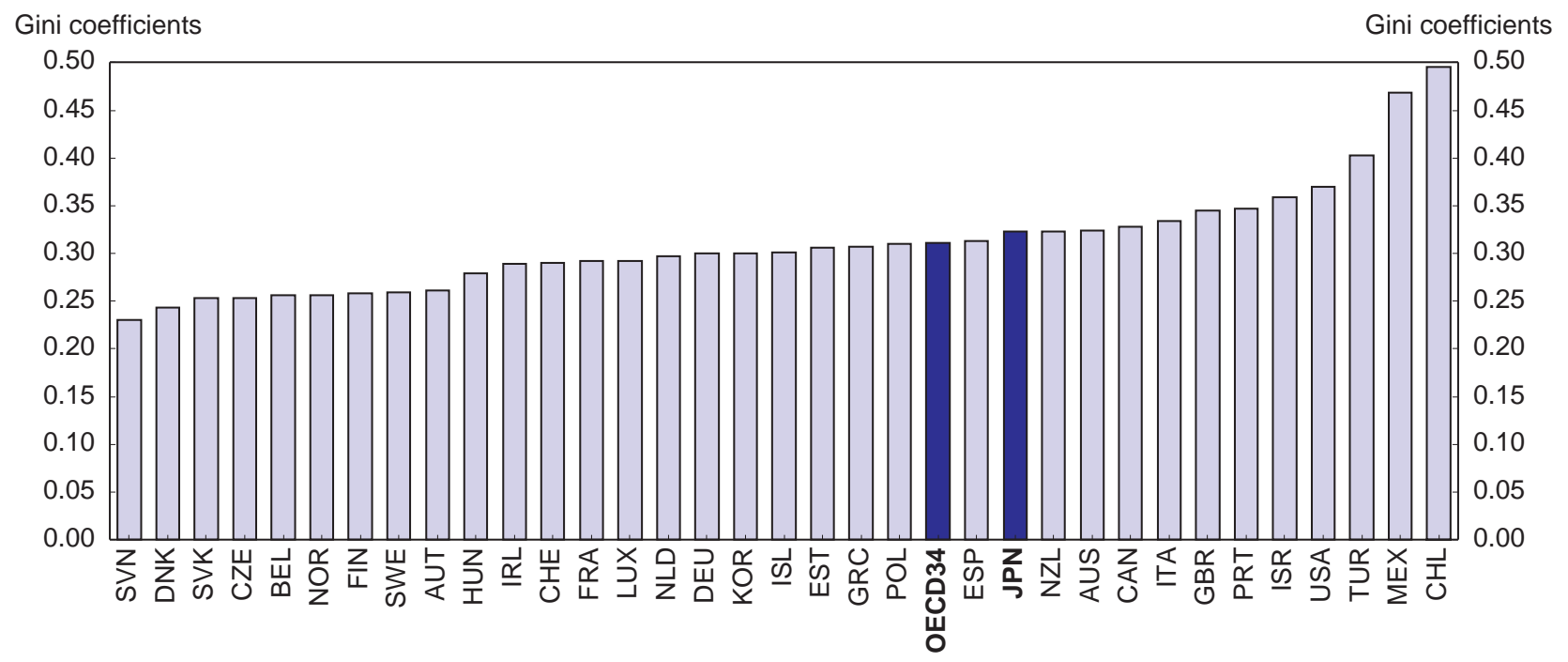

Note: The Gini coefficient ranges from 0 (perfect equality) to 1 (perfect inequality) and refers to disposable household income for the working-age population.

Source: OECD 2011, Divided We Stand.

The Japanese government has taken several steps, such as revising the Part-time Workers Law in 2007 to prevent discrimination against part-time workers and extending the coverage of employment insurance in 2009 and 2010. Since the 2010 extension, 2.2 million workers who were not previously covered have obtained access to social insurance coverage.

\section{Enhancing redistribution through taxes and benefits}

The level of redistribution via cash transfers and income taxes is lower in Japan than in most other OECD countries (Figure 2). Although taxes and benefits reduced inequality by $17 \%$ in 2006 , up from $11 \%$ in 1985 , it was well below the OECD average of $25 \%$. 


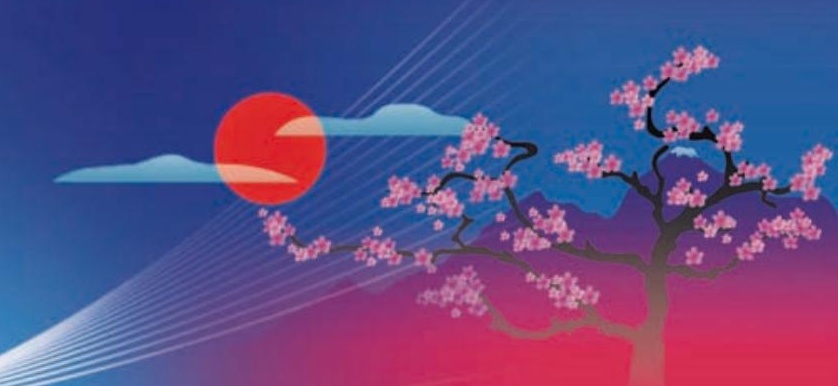

Figure 2. Reduction of income inequality through cash transfers and income taxes, late 2000s

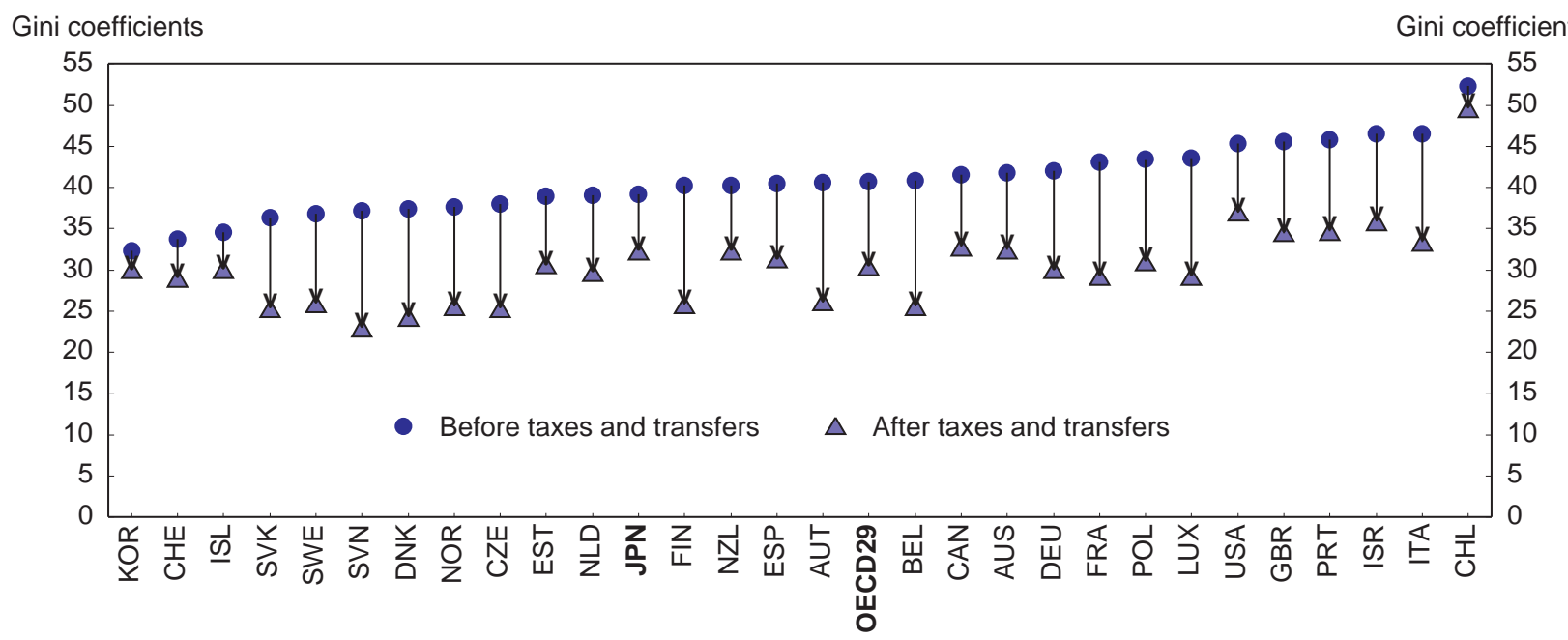

Note: The Gini coefficient ranges from 0 (perfect equality) to 1 (perfect inequality). Market incomes are all gross incomes from earnings, savings and capital. Disposable income adds transfers and subtracts taxes. Estimates refer to the working-age population. Source: OECD 2011, Divided We Stand.

While Japan's overall public social spending is at the OECD average of 20\% of GDP, it is concentrated on old-age and health expenditures. Income support to the working-age population represents $1.7 \%$ of GDP, less than half the OECD average. As a result, cash transfers account for only a fifth of the income of poorer households, against about half on average across the OECD. The income tax system is also less progressive than in other OECD countries and high-income earners benefit from substantial tax employment income deductions.

\section{Key OECD Recommendations}

- Reduce labour market dualism by narrowing the disparity in employment protection between regular and non-regular workers.

- Improve the situation of non-regular workers by expanding the social protection coverage of non-regular workers and reduce the cost advantages of hiring non-regular workers.

- Expand training of non-regular workers to increase their chances of securing regular employment.

- Step up plans to create a Japanese national vocational qualification system.

- Strengthen in-work benefits, notably by introducing an earned income tax credit, which would increase work incentives. 


\section{Reducing gender inequality}

Reducing persistent gender inequalities in economic opportunities and outcomes is essential for fairness and equity, as well as to support Japan's long-term growth. In particular, greater female labour force participation would help mitigate the effects of rapid population ageing. If female participation rates were to converge to male levels over the next 20 years, Japan could avoid a dramatic decline of its labour force and the associated fall in potential growth (Figure 1). But raising female participation requires a comprehensive approach, with actions on several fronts.

Figure 1. Japan needs more gender equality to mitigate the decline of its labour force.

Projected number of persons aged 15-64 in the labour force, in thousands, 2010-2030

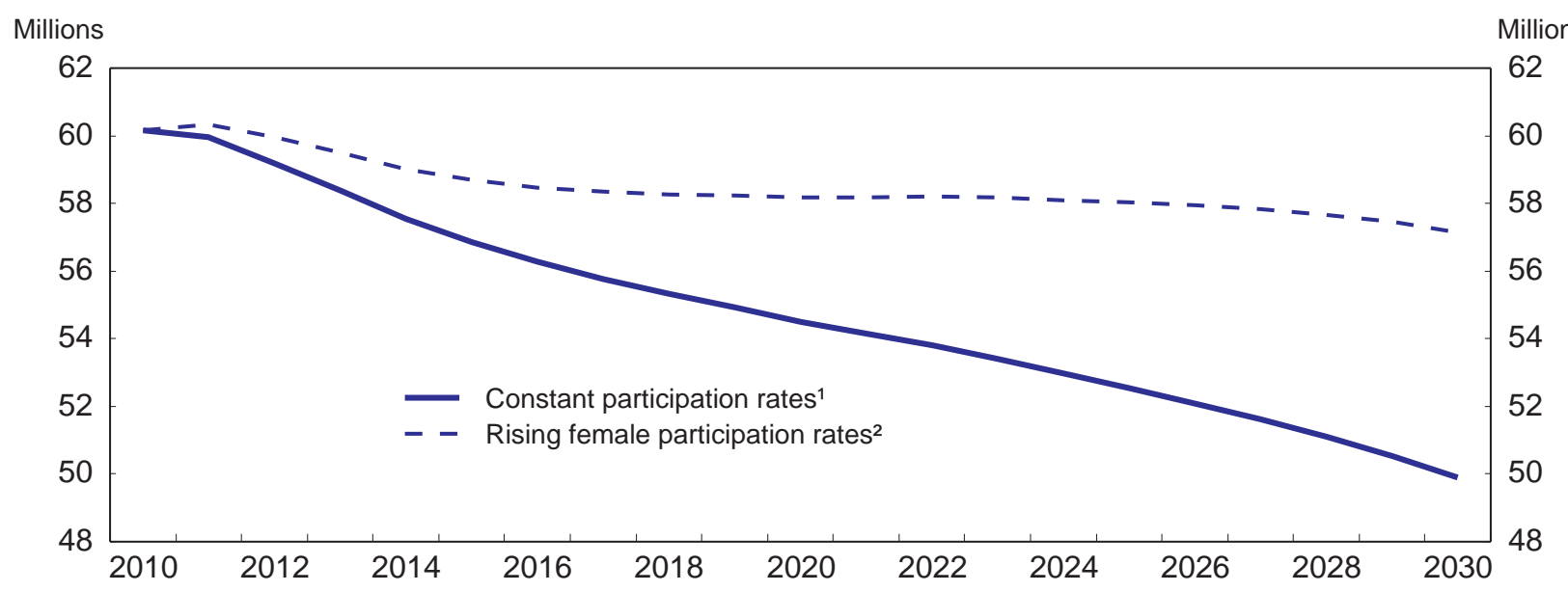

1. No-change scenario: the labour force participation rates for men and women remain constant from 2011 to 2030 at the rates observed in 2010.

2. Convergence in participation rates: the rate for women shows a gradual increase (steady growth rate) from 2011 to 2030 reaching the 2010 rate for men by 2030.

Source: OECD's calculations based on OECD Population and Demography and OECD Employment Databases.

\section{Giving better employment opportunities to women}

Gender pay differences in Japan are the second largest in the OECD (Figure 2). Japanese parents and public invest in education irrespective of gender, and girls do as well as boys in school. However, students' field of specialisation differs substantially by gender and female employees are concentrated in the medical and welfare sectors, but they are under-represented among academics, in the technology sector and among public servants. Furthermore, women are less likely to be in regular employment and thus account for $70 \%$ of the relatively lowpaid non-regular workers. When in regular jobs, women often end up in support and administrative positions ('ippanshoku'), rather than career tracks for management positions ('sougoushoku'). A glass ceiling seems to block women's advancement to senior management positions.

\section{Changing labour market institutions and employment practices}

Giving women better chances to pursue economic opportunities requires changes in labour market institutions and employment practices to better balance work and family responsibilities. Traditional notions of gender roles remain important in Japanese society. Although women tend to continue working after marriage, around $60 \%$ withdraw from the labour market at the time of childbirth. Compared with other OECD countries, the difficulties to combine work and family life are compounded by long working hours for workers who often work unpaid overtime and dine with colleagues. Together with Korea, Japan has the largest gender difference in unpaid work (household chores or caring for other family members). While policies encourage men to take parental leave, not many use this opportunity, as it may be seen as a lack of commitment to the employer. Mothers returning to work face difficulties in finding regular jobs, in part due to age-barriers to entry into regular employment. Over $50 \%$ of women work part-time or as temporary agency ("dispatched") workers, which are usually classified as non-regular employment. 


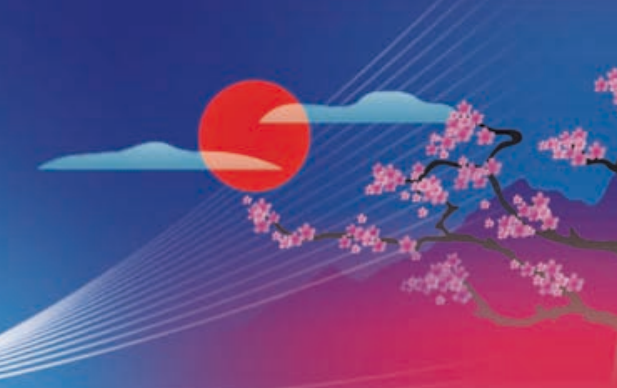

Figure 2. The Gender pay gap ${ }^{1}$ in Japan is the second largest in the OECD, 2010 ${ }^{2}$

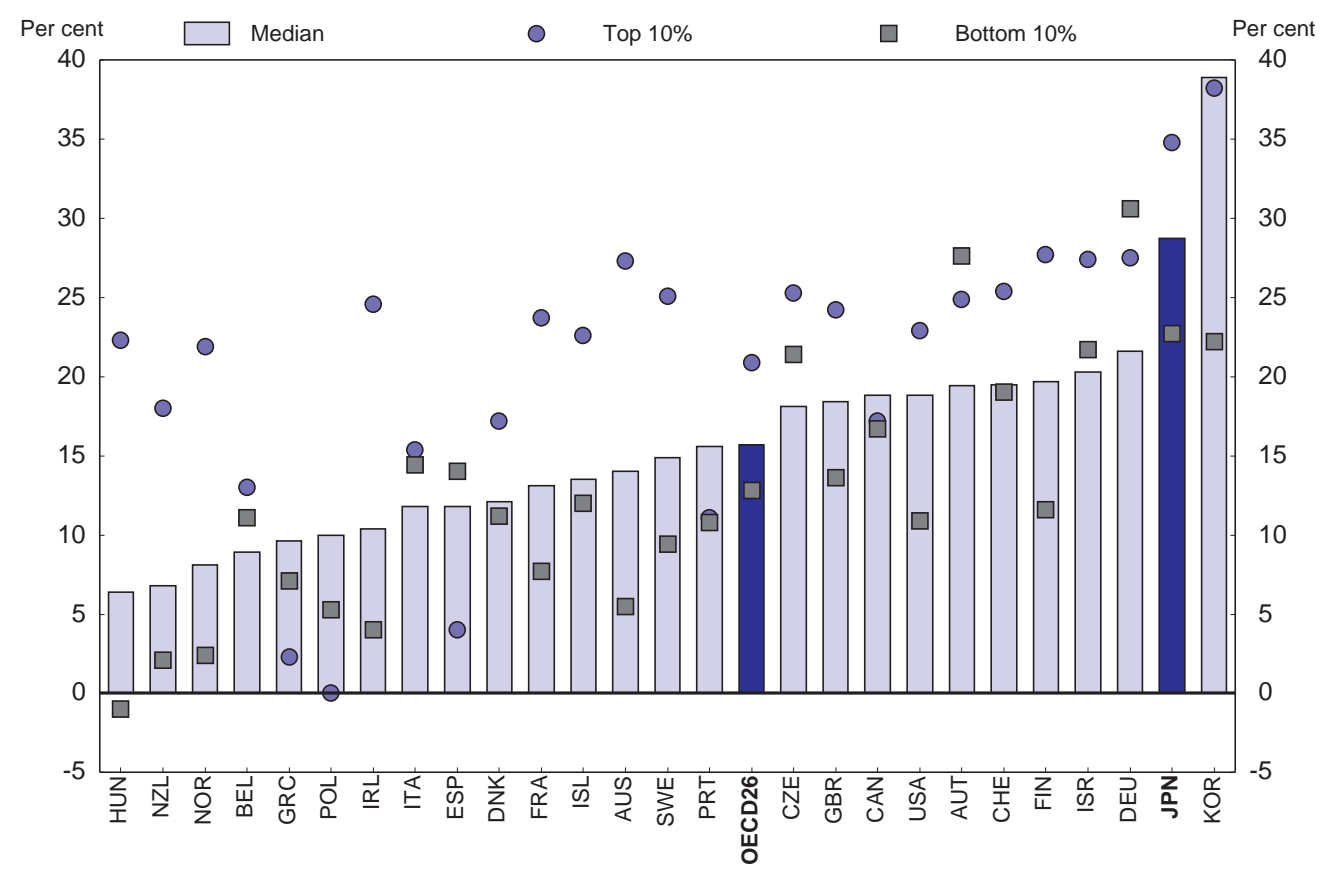

1. Defined as the difference between male and female wages divided by male wages (at the 1st decile, median and 9th decile of the earnings distribution).

2. Data refers to 2009 for Austria, the Czech Republic, Denmark, Finland, Germany, Ireland, Israel, Korea, Sweden, and Switzerland, to 2008 for Belgium, France, Greece, Iceland, Italy, Poland, Portugal, and Spain.

Source: OECD Employment Database.

Returning mothers are also severely affected by the seniority-pay system, which sanctions taking time off from work beyond the parental leave entitlement. Earnings and career profiles need to more closely reflect performance rather than seniority, and workplaces have to become more family-friendly, which would also allow men to do their fair share of unpaid work at home.

The government has increased support for early childhood education and care, but more is needed. Also, the tax/benefit system still provides disincentives for second earners in couple-families to work more because of provisions giving married women strong incentives to limit their labour force participation.

\section{Key OECD recommendations}

- Raise awareness among young women about the likely consequences of their educational and occupational choices for career and earnings progression through information campaigns and school-counselling.

- Encourage changes in the workplace culture, which promotes long working hours and limits mens' use of family-friendly workplace measures (including annual and parental leave entitlements), by reforming remuneration and career systems. This should include giving greater importance to performance over seniority in determining pay and providing bonuses to managers whose staff make use of their leave entitlements.

- Provide high-quality affordable childcare to all parents and encourage a more equal sharing of parental leave.

- Reform the tax/benefit system so that work pays for both parents.

- Set realistic and measurable targets for female representation in senior management in the public and private sectors. 


\section{Making growth greener}

\section{Green growth}

Green growth, and notably the promotion of "green innovation" (i.e., innovation to achieve a resource-efficient and low-carbon society, in order to secure stable energy supply and address climate change), is central in Strategies to Revitalise Japan. This approach is closely in line with the ongoing OECD Green Growth Strategy. Eco-innovation has long been a key feature of Japan's environmental policy, driven by close collaboration between the government and the business sector. The government has in particular deployed a range of measures to stimulate demand for green products, including voluntary agreements and performance targets established with the business sector (including the Top Runner programme), green procurement, and an environmental technology verification programme. In addition, environmentally related R\&D expenditure has increased considerably, especially in the private sector. All this has helped Japan to rank as the second most innovative country in environmental technologies in 2008.

More cost-effective policy instruments, particularly market-based instruments that apply to the economy as a whole, would provide better incentives for achieving environmental objectives and for promoting eco-innovation. In addition, it would enable Japan to reduce greenhouse gas (GHG) emissions in a cost-efficient manner. Some progress has already been made in using market-based instruments, notably with the introduction of a coal tax and a $\mathrm{CO}_{2}$ voluntary emissions trading system. However, tax rates on energy products, including transport fuels, are among the lowest in the OECD and do not adequately reflect environmental and other social costs. Revenue from environmentally related taxes has increased since 2000, but still accounts for a lower share of GDP than in most other OECD countries (Figure). Broadening the use of such taxes would also generate revenue that could help fiscal consolidation and make the tax system more growth-friendly. The increase in petroleum and coal tax rate (according to $\mathrm{CO}_{2}$ emissions) in FY 2012 is a welcome step.

Revenue from environmentally related taxes (per cent of GDP, 2010)

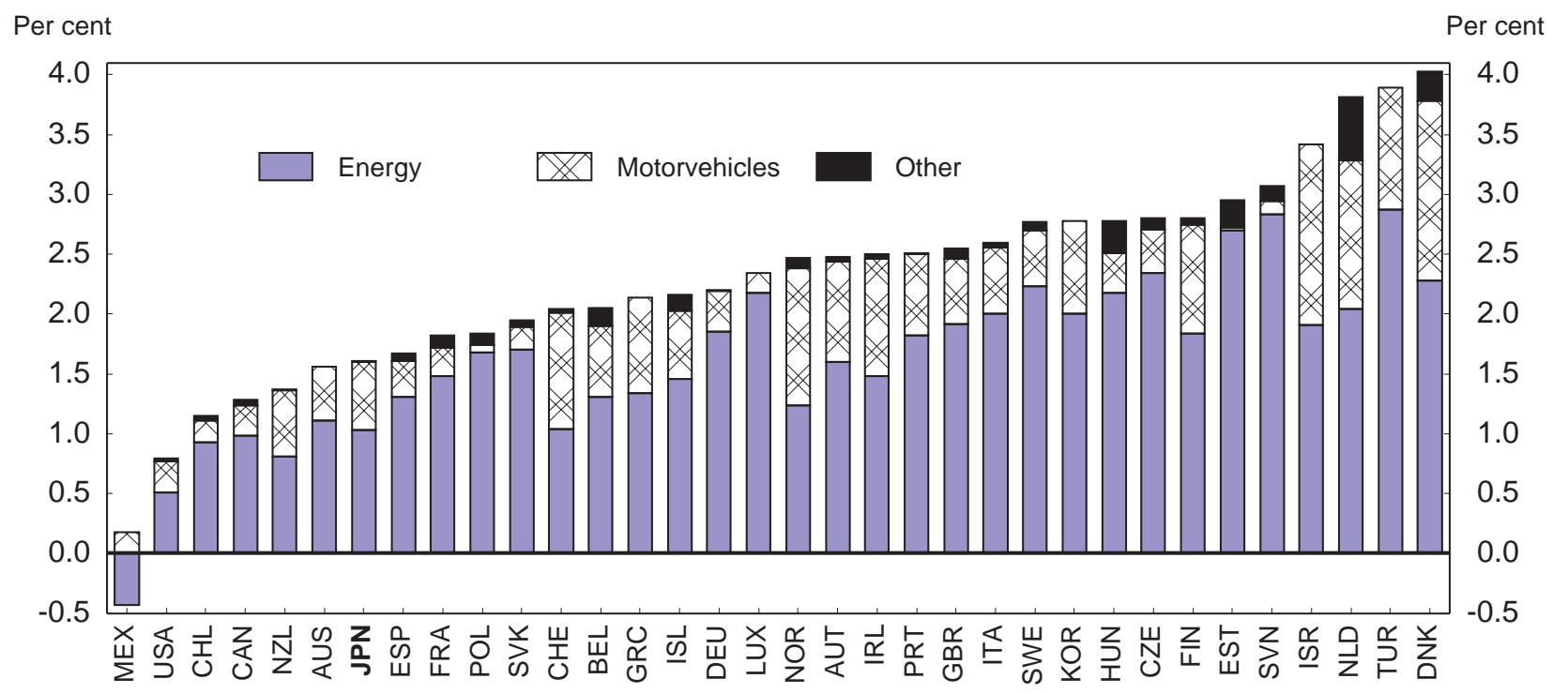

Source: OECD/EEA Database On Instruments Used For Environmental Policy.

Moreover, including environmental and social costs in the price of goods and services would be more appropriate than stimulating industries and consumers to purchase environmentally friendly products by providing various subsidies (e.g., tax breaks for fuel-efficient vehicles). Such subsidies encourage greater use of the subsidised products, potentially offsetting the technical efficiency gains, and are a cost to the already strained public finances. 


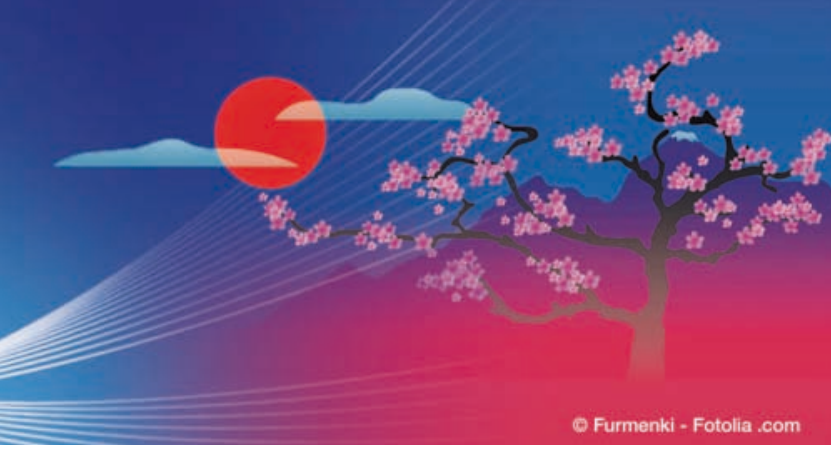

\section{Energy and climate change policies}

Energy security issues are more critical for Japan than for most countries due to its geographical location and limited domestic energy resources. Currently, the activity of almost all Japan's nuclear reactors remains suspended after a temporary shutdown for periodic inspection and "stress-tests". As nuclear energy was providing around 30\% of Japan's electricity before the crisis, this has triggered a dramatic increase in fossil fuel use for energy generation, even though industry and households were requested to limit their energy consumption.

While nuclear energy is facing serious challenges, including the recovery of contaminated land and the decommissioning of damaged reactors, a long-term shutdown of nuclear reactors would challenge Japan's objectives of ensuring its security of supply, providing a reliable supply of low cost electricity and reducing $\mathrm{CO}_{2}$ emissions. A rising share of fossil fuels, especially coal, in the energy mix was the main driver of growing GHG emissions during most of the 2000s, and this has worsened with the reduced share of nuclear power after March 2011.

On the other hand, while Japan is a world leader in renewable energy technologies, and generation capacity has increased, renewables accounted for only about 3\% of energy supply in 2010. The current technologyspecific support and short-term targets limit investor flexibility, thus potentially increasing overall costs. A fragmented electricity grid is also an obstacle to a more extensive use of some renewable energy sources, such as wind and solar photovoltaic.

Japan will introduce a feed-in-tariff system from July 2012 to facilitate the use of renewable energy. In other OECD countries, the combination of a guaranteed price premium for renewable energy producers, a guaranteed market for producers and the independence of the scheme from the general budget have provided a predictable and credible long-term price signal to potential investors, thereby resulting in successful outcomes.

\section{Key OECD recommendations}

- Continue to broaden the use of environmentally related taxes and reduce incentives and subsidies that have perverse effects on growth and environment.

- Put a consistent price on carbon, for example through a mandatory emissions trading scheme in combination with a carbon tax that applies to those emissions not covered under the scheme.

- Expand the use of economic instruments, review the cost-effectiveness of regulatory instruments and voluntary agreements negotiated with industry.

- Further expand public investment in basic R\&D in environment- and climate-related technologies, analyse the effectiveness and dynamic efficiency of current performance targets (e.g., the Top Runner Programme) in inducing eco-innovation and adjust as appropriate.

- Establish a consistent and long-term framework to develop renewable energy sources and reduce reliance on fossil fuels, avoiding technology-specific targets.

- Based on the review of the Strategic Energy Plan, ensure that all energy technologies, including nuclear power, are given due consideration to meet the goals of ensuring security of supply, reducing CO2 emissions and maintaining affordable electricity prices. 


\section{Reforming agricultural policy}

Challenges in the agricultural sector were exacerbated by the Great East Japan Earthquake. This has reinforced the need to move toward a more competitive and sustainable sector, while allowing deeper economic integration with its economic partners. Successful policy reform would create potential opportunities for farmers to produce high-quality and high-value products and allow the government to better target policy interventions to specific objectives (such as transitory income support and the preservation of paddy land). Although Japan has already taken steps toward agricultural policy reform, much more remains to be done.

\section{Enhancing the growth potential of Japan's agricultural sector}

Japan's agricultural sector has strong growth potential and the capacity to produce new, higher-value products. Since the domestic food market is expected to contract in the long term, future opportunities for growth have to come from these higher-value products and new overseas markets. Thus, the reform process should create a framework that enables famers to compete domestically, to improve productivity and efficiency, and to exploit new markets abroad. A major step would be the reduction in trade barriers that limit competitiveness, reduce opportunities for farmers, and prevent the economy as a whole from benefitting from increased trade and greater participation in regional trade agreements, including the Trans-Pacific Partnership (TPP).

A first step is to reform the supply management policy that aims at maintaining high domestic prices relative to world prices for several commodities. Second, reforms of other forms of producer support that are linked directly to commodity production are needed. Such support is among the most market-distorting forms of support and least effective means of improving farm income. Both reforms will facilitate needed structural adjustments and enhance competitiveness; they would also be in line with trends in other major OECD countries to reduce support levels and significantly increase the share of payments that are not tied to the production of a specific commodity (Figure).

Japanese farmers are already adjusting production toward high value-added sectors, which receive much less or even no support. For instance, although rice benefits from the highest level of support among major commodities, its share in production value has declined from 50\% in 1960 to less than 20\% in 2010, while livestock and vegetables now account for almost $60 \%$. Decoupling support from specific commodity production would give farmers greater incentives to seek better opportunities in these markets.

\section{Targeting agricultural policies to Japan's policy objectives}

Decoupling support from production decisions would not only promote structural adjustment toward high value-added sectors, but would also allow the government to target payments to specific policy objectives.

To ensure a comparable level of farm income under competitive markets, payments could be targeted to specific farm groups suffering from income losses and in particular to farms that depend predominantly on farming income (such farms account for only one-fifth of the total commercial farm households). Businessoriented, full-time farmers could also benefit from new policies targeting their specific needs (for instance to increase their productivity growth, make the use of resources more sustainable, expand the tool kit of available risk management instruments).

Second, policies aimed at encouraging farmers to use paddy land extensively would support Japan's objective of preserving the amount of paddy land for environmental and food security. The current practice of limiting rice production to maintain high domestic prices conflicts with this policy objective. Shifting toward policies that encourage extensive production and lower rice prices would increase domestic demand and open the possibility of exports to high-end world markets. 


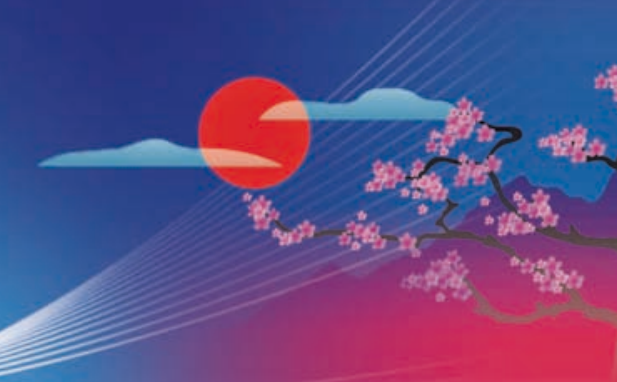

Level and composition of producer support in selected OECD countries

Producer Support Estimate (PSE) as a per cent of gross farm receipts

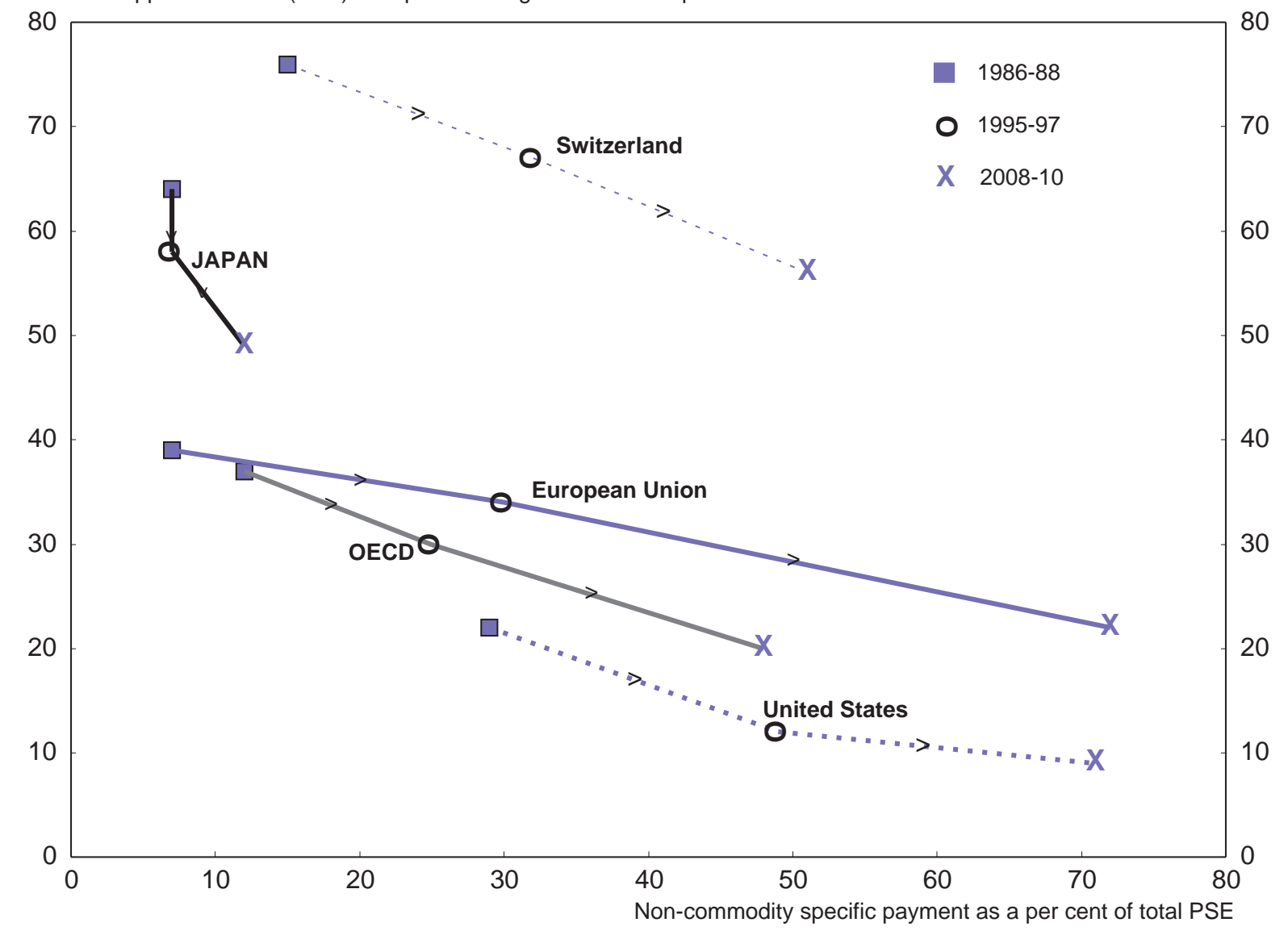

Source: OECD PSE/CSE Database.

\section{Key OECD recommendations}

- Create a policy framework that enables farmers to compete domestically and create scope for exports.

- Target income support, where necessary, to those dependent on farming income.

- Scale back production adjustment of rice and encourage extensive use of paddy land, thereby lowering prices and encouraging rice consumption, while preserving paddy land.

- Move away from price support to decoupled payments that do not require the production of certain commodities, therefore also facilitating Japan’s participation in regional trade agreements. 


\section{Measuring well-being and progress}

\section{Japan's approach is in line with the OECD Better Life Initiative}

Japan has put improving the quality of people's lives high on its political agenda. Public policies can only deliver on this ambitious agenda if they are based on reliable tools to measure what makes for a "good life". Traditional economic indicators do not tell the whole story, and a more comprehensive and balanced assessment of well-being and progress is needed.

Recognising the need for better indicators of well-being, the New Growth Strategy called for the development of well-being measures that would be useful for policy. A Commission on Measuring Well-Being, established by the Minister of State for Economic and Fiscal Policy and composed of academics from renowned Japanese universities, conducted research on well-being and happiness and proposed about 130 indicators to assess and monitor the Japanese government's endeavour "to create a better society that provides not only economic wealth but also overall well-being". The proposed indicators are organised around three main pillars: economic and social conditions, physical and mental health, and relatedness. In addition, sustainability indicators are also included to provide a longer-term perspective on these three pillars. Based on such a structure, the Japanese government conducted a survey of about 10000 citizens in March 2012. In addition, a number of local governments in Japan have also been tackling the measurement of well-being at local level.

The initiative pursued by Japan is consistent with the goal of the OECD Better Life Initiative to bring to the attention of citizens and policy-makers a comprehensive set of indicators encompassing the different areas that matter for people's lives. Developing better measures of well-being is not an end in itself. It is a means to enhance policies that improve the lives of people and foster the progress of societies.

How does life compare in Japan?

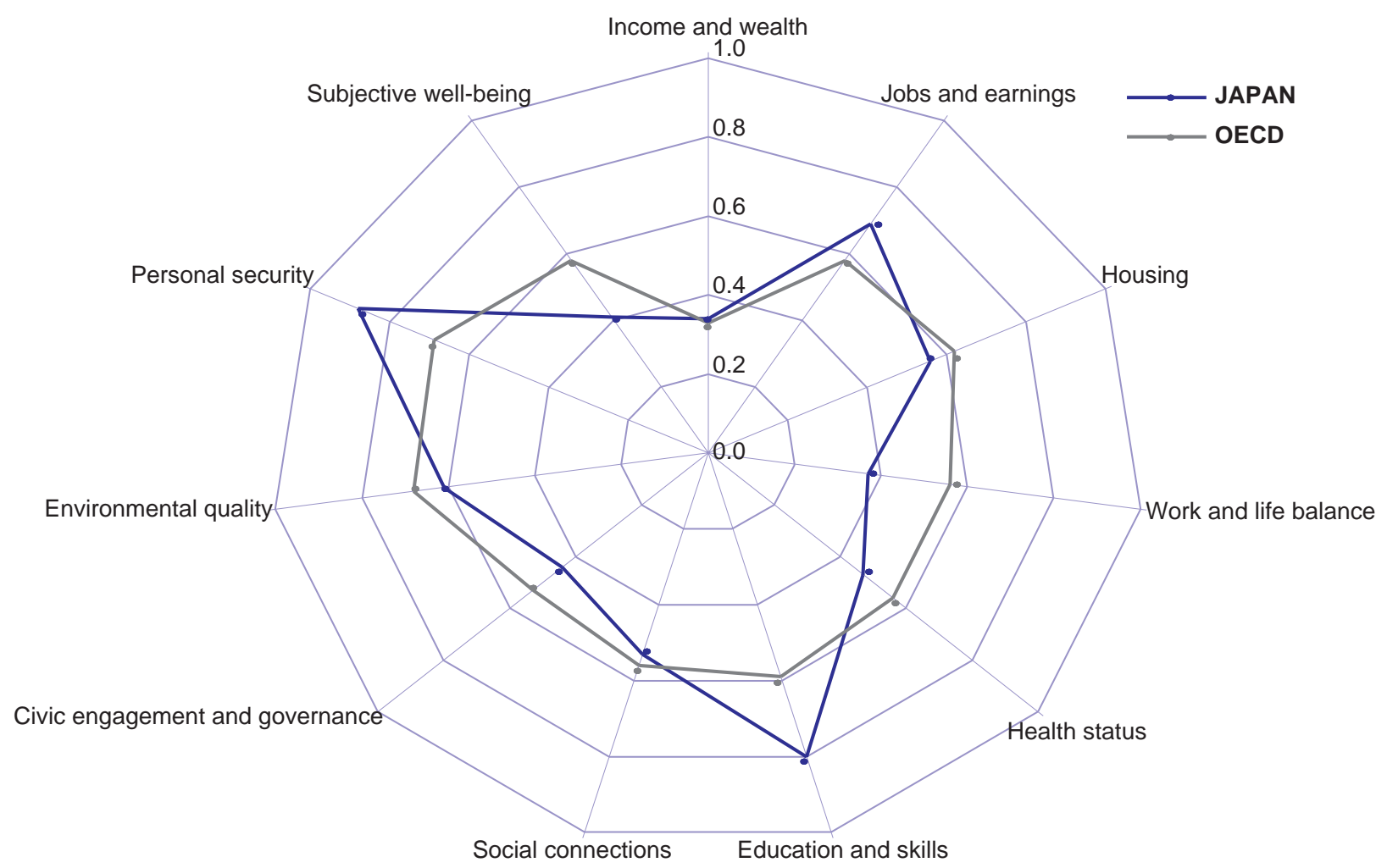

Source: OECD (2011), How's Life? 


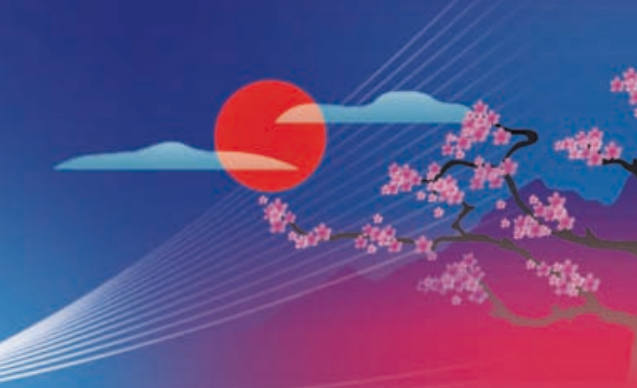

\section{How's life in Japan?}

Based on the evidence contained in the OECD How's Life? report, Japan performs favourably in most objective measures of well-being, compared with other OECD countries, and ranks close to the OECD average or higher in several dimensions. In particular:

- Household net adjusted disposable income per capita, which provides the most extensive measure of people's economic resources, is just above the OECD average.

- Nearly $70 \%$ of people aged 15 to 64 have a paid job, compared with $65 \%$ on average in the OECD.

- In Japan, $87 \%$ of adults aged 25 to 64 have earned the equivalent of a high-school diploma, one of the highest rates in the OECD.

- Japan is also a top-performing country in terms of the quality of its educational system. The average Japanese student scored 520 out of 600 in reading ability according to the latest PISA student-assessment programme, well above the OECD average.

- In terms of health, life expectancy at birth in Japan is 82.7 years, the highest rate in the OECD, despite some concerns about air pollution.

- Concerning the public sphere, even though the voter turnout is lower than the OECD average, there is a strong sense of community among Japanese people.

However, Japan displays a striking difference between the relatively favourable picture drawn from objective measures of well-being and the assessment derived from looking at subjective well-being indicators. Indeed, when asked about their overall life satisfaction, only $40 \%$ of people in Japan said they were satisfied with their life, well below the OECD average of 59\%.

The relatively large gap observed between objective and subjective measures of well-being could be symptomatic of genuine problems in the Japanese society, or it might instead reflect a cultural reluctance by Japanese citizens to report high scores when asked to rate their life as a whole. More research is needed on the impact of subjective life satisfaction in Japan, and its potential links to high work and commuting time, rising inequality, feelings of isolation and concerns about the future.

\section{Key OECD recommendations}

- Build on the recommendations of the Commission on Measuring Well-Being and the March 2012 Survey.

- Continue to consult citizens, social partners and civil society organisations in order to identify the dimensions of well-being that matter the most in Japanese society, and where regular monitoring and reporting would be required.

- Assess the available data and indicators that could provide information on various dimensions of people's well-being, social conditions and equity challenges in the country; and mobilise its statistical and analytical capacities for developing new measures of well-being where needed.

- Incorporate a broader notion of well-being into the policy process, by requiring that sectoral policies and programmes are assessed for their impacts on different aspects of well-being before being implemented, as is the case in Australia and New Zealand, for example.

- Seek to understand better the reasons for the low levels of life satisfaction in Japan and raise these issues on the political agenda when needed. 



\section{ORGANISATION FOR ECONOMIC CO-OPERATION AND DEVELOPMENT}

The OECD is a unique forum where governments work together to address the economic, social and environmental challenges of globalisation. The OECD is also at the forefront of efforts to understand and to help governments respond to new developments and concerns, such as corporate governance, the information economy and the challenges of an ageing population. The Organisation provides a setting where governments can compare policy experiences, seek answers to common problems, identify good practice and work to co-ordinate domestic and international policies.

The OECD member countries are: Australia, Austria, Belgium, Canada, Chile, the Czech Republic, Denmark, Estonia, Finland, France, Germany, Greece, Hungary, Iceland, Ireland, Israel, Italy, Japan, Korea, Luxembourg, Mexico, the Netherlands, New Zealand, Norway, Poland, Portugal, the Slovak Republic, Slovenia, Spain, Sweden, Switzerland, Turkey, the United Kingdom and the United States. The European Union takes part in the work of the OECD.

OECD Publishing disseminates widely the results of the Organisation's statistics gathering and research on economic, social and environmental issues, as well as the conventions, guidelines and standards agreed by its members.

\section{OECD “Better Policies” Series}

The Organisation for Economic Co-operation and Development (OECD) aims to promote better policies for better lives by providing a forum in which governments gather to share experiences and seek solutions to common problems. We work with our 34 members, key partners and over 100 countries to better understand what drives economic, social and environmental change in order to foster the well-being of people around the world. The OECD Better Policies Series provides an overview of the key challenges faced by individual countries and our main policy recommendations to address them. Drawing on the OECD's expertise in comparing country experiences and identifying best practices, the Better Policies Series tailor the OECD's policy advice to the specific and timely priorities of member and partner countries, focusing on how governments can make reform happen. 
